\title{
Dentalion (Hymenoptera: Eulophidae: Entedoninae) a new genus from tropical America with eleven new species
}

\author{
CHRISTER HANSSON \\ Entomology Department, the Natural History Museum, Cromwell Road, London SW7 5BD, United Kingdom. \\ E-mail: christerdennis@gmail.com
}

\begin{abstract}
Dentalion gen. nov. (Hymenoptera: Eulophidae: Entedoninae), is described from the northern part of the Neotropical region, from Costa Rica to Ecuador and Brazil, and the Caribbean (Trinidad \& Tobago). It comprises eleven new species: D. alveum, D. ambonatum, D. apertum, D. apon, D. crassicornis, D. jimenezi, D. mischum, D. noyesi, D. pinguicornis, $D$. pnigaliae, D. quadrifer. These species are diagnosed, described and illustrated, and a key for their identification is provided. Dentalion is characterized by two putative autapomorphies and two synapomorphies. The phylogenetic implications of these apomorphies are discussed briefly.
\end{abstract}

Key words: neotropical, identification key, taxonomy

\section{Introduction}

This is a contribution to the knowledge of the eulophid fauna in the Neotropical region. The fauna in this part of the world has had several major additions during the last ten years, e.g. Hansson 2002, 2004, 2009a and Schauff et al. 2001. However, in spite of these recent taxonomic treatments several genera of the subfamily Entedoninae, the group to which most additions have been made, remain untreated and some of these have not been described yet. These undescribed taxa possess information that is unavailable and are thus unable to inform hypotheses on the classification and relationships of the subfamily. The new genus described here, Dentalion, is very distinct and is easily recognized because of the presence of a single tooth on the hind femora, which is a unique feature within the subfamily. Another derived feature suggests a sister-group relationship with Emersonella Girault, a genus comprising 58 species that are confined to the Americas, with the majority of species occurring in tropical America.

\section{Morphological abbreviations and acronyms}

Abbreviations of morphological terms: $\mathrm{HE}=$ height of eye; $\mathrm{HW}=$ height of forewing; $\mathrm{LG}=$ length of gaster; $\mathrm{LM}=$ length of marginal vein; LW = length of forewing, measured from base of marginal vein to apex of wing; $\mathrm{MM}=$ length of mesosoma; $\mathrm{MS}=$ malar space; $\mathrm{OOL}=$ distance between one posterior ocellus and eye; $\mathrm{PM}=$ length of postmarginal vein; POL $=$ distance between posterior ocelli; $\mathrm{POO}=$ distance between posterior ocelli and occipital margin; ST = length of stigmal vein; WH = width of head; WM = width of mouth; WT = width of thorax. For illustrations of the morphological terms see www.neotropicaleulophidae.com.

Collection acronyms used in this article are: $\mathrm{BMNH}=$ The Natural History Museum, London, England; CNC = Canadian National Collection of Insects, Arachnids and Nematodes, Ottawa; INBio = Instituto Nacional de Biodiversidad, Santo Domingo, Costa Rica.

The ratios of morphological measurements, summarized in Table 1, are based on the holotype and one paratype (if present) of the other sex. 
TABLE 1. Ratios between different body parts. For explanations of morphological abbreviations see section "Morphological abbreviations and acronyms" above.

\begin{tabular}{lllllll}
\hline & HE/MS/WM & POL/OOL/POO & WH/WT & LW/LM/HW & PM/ST & MM/LG \\
\hline D. alveum sp. nov., female & $2.3 / 1.0 / 1.4$ & $3.0 / 1.8 / 1.0$ & 1.2 & $1.7 / 1.0 / 1.0$ & 1.3 & $0.8-1.0$ \\
D. ambonatum sp. nov., female & $2.4 / 1.0 / 1.7$ & $3.9 / 1.4 / 1.0$ & 1.2 & $1.7 / 1.2 / 1.0$ & 2.3 & 0.8 \\
D. apertum sp. nov., female & $1.9 / 1.0 / 1.5$ & $3.6 / 1.7 / 1.0$ & 1.1 & $1.8 / 1.1 / 1.0$ & 2.4 & 0.8 \\
D. apon sp. nov., female & $2.2 / 1.0 / 1.5$ & $3.5 / 1.0 / 1.0$ & 1.3 & $1.7 / 1.1 / 1.0$ & 2.0 & 0.8 \\
D. apon sp. nov., male & $2.2 / 1.0 / 1.5$ & & & & 1.0 \\
D. crassicornis sp. nov., female & $2.6 / 1.0 / 1.5$ & $2.4 / 1.2 / 1.0$ & 1.1 & $1.7 / 1.1 / 1.0$ & 1.5 & 0.8 \\
D. jimenezi sp. nov., female & $2.2 / 1.0 / 1.4$ & $4.3 / 1.8 / 1.0$ & 1.3 & $1.7 / 1.2 / 1.0$ & 1.9 & $0.7-0.8$ \\
D. jimenezi sp. nov., male & $2.1 / 1.0 / 1.5$ & & & & $1.0-1.1$ \\
D. mischum sp. nov., female & $2.0 / 1.0 / 1.3$ & $4.1 / 2.3 / 1.0$ & 1.2 & $1.8 / 1.3 / 1.0$ & 2.8 & 0.8 \\
D. noyesi sp. nov., female & $2.5 / 1.0 / 1.6$ & $2.3 / 1.0 / 1.0$ & 1.2 & $1.8 / 1.2 / 1.0$ & 2.0 & 0.7 \\
D. pinguicornis sp. nov., female & $2.1 / 1.0 / 1.5$ & $3.0 / 1.6 / 1.0$ & 1.1 & $1.8 / 1.2 / 1.0$ & 2.7 & 1.0 \\
D. pinguicornis sp. nov., male & $2.2 / 1.0 / 1.7$ & & & & 1.0 \\
D. pnigaliae sp. nov., female & $2.3 / 1.0 / 1.7$ & $3.6 / 2.0 / 1.0$ & 1.1 & $1.8 / 1.1 / 1.0$ & 3.0 & 0.9 \\
D. quadrifer sp. nov., female & $2.4 / 1.0 / 1.4$ & $2.8 / 1.0 / 1.1$ & 1.1 & $1.9 / 1.3 / 1.0$ & 2.7 & 0.9 \\
\hline
\end{tabular}

\section{Dentalion Hansson gen. nov.}

Type species: Dentalion pinguicornis sp. nov., designated here.

Etymology. Named for the tooth on the medioventral part of the hind femora, from the Latin dentis = tooth. The gender is neuter.

Diagnosis. Frontal suture V-shaped in a narrow angle (usually $35-60^{\circ}$ ), and reaching eyes high up on frons (e.g. Figs 6, 10, 14); antennal scrobes wide and indistinctly delimited (e.g. Figs 2, 6, 10); lateral panels of metanotum divided into two about equal-sized parts by a longitudinal carina (Fig. 48); hind femur with a tooth medioventrally (Fig. 49); postmarginal vein always longer (1.3-3.0X) than stigmal vein.

Description. Female flagellum with a 2-segmented clava (e.g. Figs 56-58), in male with all 5 flagellomeres distinctly separated (Figs 60, 64, 67); male flagellomeres with scattered setae; male scape slightly wider than in female (Figs, 60, 64, 67), with ventral sense area present along entire scape; sensilla ampullacea globular, symmetric (type I sensu Hansson (1990)), present on all flagellomeres. Antenna with discoid anelli. Mandibles with three large teeth at apex. Clypeus not delimited. Malar sulcus missing, sometimes indicated by fine small meshed reticulation. Frontal suture V-shaped in a narrow angle, usually $35-60^{\circ}$ (e.g. Figs 6, 10, 14) but in one species $85^{\circ}$ (Fig. 2). Antennal scrobes joining frontal suture separately (e.g. Figs 6, 10, 14). Occipital margin rounded; occiput without a median fold or groove between occipital margin and occipital foramen.

Pronotum usually without transverse carina close to posterior margin (e.g. Figs 21, 24, 28), but in one species with a weak carina (Fig. 7). Midlobe of mesoscutum with 2 pairs of setae; notauli distinct and narrow in anterior $1 /$ 3, in posterior 2/3 either not visible (Fig. 44), or as indistinct impressions (Fig. 28), or as distinct wide grooves (Fig. 7), or as rows of foveae (Fig. 4). Scutellum with 1 or 2 pairs of setae (e.g. Figs 7, 11). Transepimeral sulcus wide and curved in a $90^{\circ}$ angle (Fig. 47). Dorsellum visible in dorsal view, with strong sculpture. Lateral panels of metanotum divided into two about equal-sized parts by a longitudinal carina (Fig. 48). Forewing with postmarginal vein 1.3-3.0X as long as stigmal vein; speculum usually closed below (Fig. 53), but open in one species (Fig. 52). Propodeum usually smooth or with irregular carinae in median part (e.g. Figs 5, 8, 18), but in one species with a complete median carina, plicae and costulae (Fig. 41); propodeal callus with 2-7 setae.

Petiole $0.2-1.8 \mathrm{X}$ as long as wide, but usually distinctly transverse, smooth and shiny. Male genitalia as in most other entedonine genera (Hansson 1996), i.e. phallobase with two equally large digital spines, volsellar setae as "normal" thin setae, parameres not protruding. 
Distribution. Brazil, Costa Rica, Ecuador, Trinidad \& Tobago.

Biology. Unknown.

Identification. Dentalion is a member of the Entedoninae, as indicated by the following combination of characters: submarginal vein with 2 setae on dorsal surface; forewing with a distinct break between submarginal and marginal veins; scutellum without sublateral grooves; flagellum with five large flagellomeres.

In the key to Nearctic genera of Eulophidae by Schauff et al. (1997), Dentalion can be separated from all other genera by the presence of a ventral dent on the hind femur (Fig. 49). Another option for identification is to use the matrix key to the Neotropical genera of Entedoninae on the website http://www.neotropicaleulophidae.com/, where also colour illustrations for each species are included.

Putative autapomorphies. Hind femur with a ventral dent (Fig. 49). Some species of Pleurotroppopsis Girault (e.g. P. podagrica (Waterston)) have a row of teeth along the ventral margin of hind femur, which is a different character state from the single tooth in Dentalion.

Frontal suture V-shaped in a narrow angle, $35-60^{\circ}$, and reaching eyes high up on frons, in level with a distance of 1.5X the diameter of one ocellus in front of anterior ocellus (Fig. 2) or behind this level (Figs 6, 10, 14, 19, 23, $27,31,35,39,43)$.

Other apomorphies, present also in other genera of Entedoninae. Lateral panels of metanotum divided into two about equal-sized parts by a longitudinal carina (Fig. 48); also present in Emersonella (Hansson 2002).

Antennal multiporous plate sensilla with upper surface concave (Fig. 50); also present in Microdonophagus Schauff (Hansson 2009b) and Inti Hansson (Hansson 2010).

Discussion. Dentalion is defined by two autapomorphies, and possess two additional apomorphies that also occur in other genera of Entedoninae. The longitudinal carina on the lateral panels of the metanotum occurs only in one other entedonine genus, Emersonella, which indicates a sister-group relationship for these two genera. Dentalion and Emersonella do not share other apomorphies, but Emersonella is characterized by six additional apomorphies (Hansson 2002) and Dentalion by two autapomorphies. The derived state of the antennal sensilla having a concave upper surface is a putative homoplasy. Apart from occurring in Dentalion, this sensillar state also occurs in two other entedonine genera, Microdonophagus and Inti, and these two genera are not closely related (Hansson 2010), clearly indicating that this character state has evolved at least twice. Dentalion does not share other apomorphies with either Microdonophagus or Inti.

\section{Key to species of Dentalion}

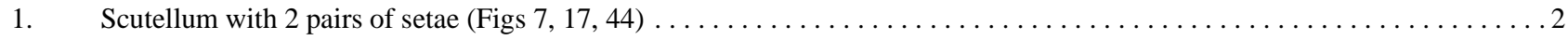

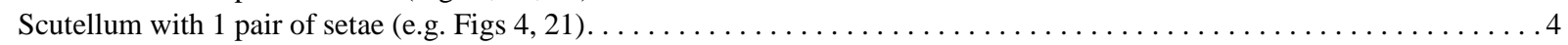

2. Notauli as distinct grooves in posterior $2 / 3$ (Fig. 7); frontal suture reaching eyes at level of anterior margin of anterior ocellus

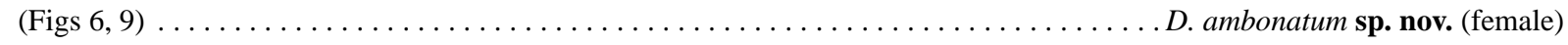
Notauli indistinct in posterior $2 / 3$ (Figs 17, 44); frontal suture reaching eyes at level of half-way between posterior margin of anterior ocellus and anterior margin of posterior ocelli (i.e. further back on head, Figs 15,46$) \ldots \ldots \ldots \ldots$

3. Frons and vertex with very strong raised reticulation (Figs 43, 46); mesoscutum and scutellum with small meshes (Fig. 44) ..

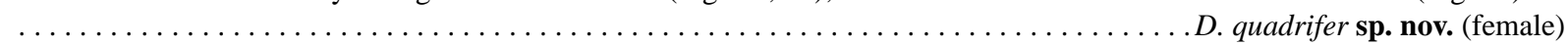
Frons and vertex with weak raised,reticulation (Figs 14, 15); mesoscutum and scutellum with large meshes (Fig. 17).......

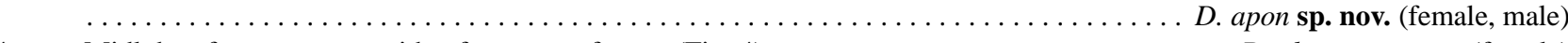

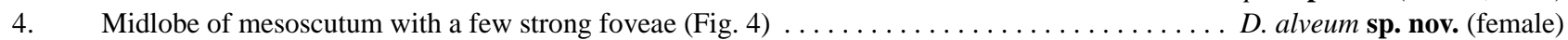

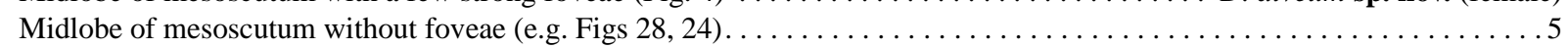

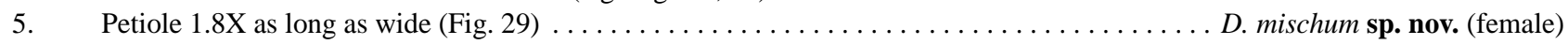

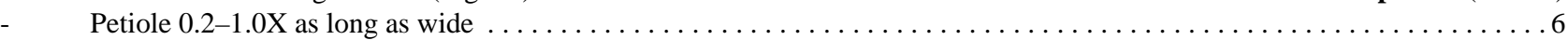

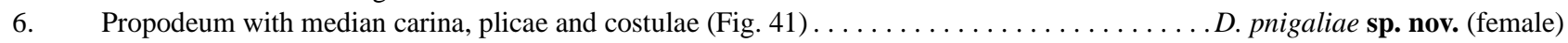

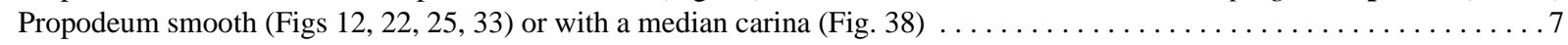

7. Frontal suture reaching eyes at a level half-way between posterior margin of anterior ocellus and anterior margin of posterior

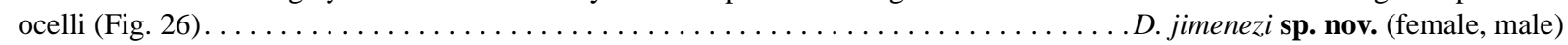
Frontal suture reaching eyes at level of anterior or posterior margin of anterior ocellus (Figs 13, 20, 34, 35) $\ldots \ldots \ldots \ldots$

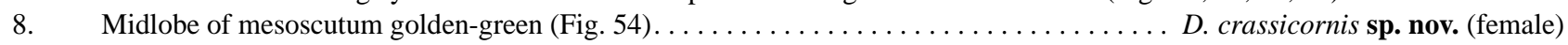

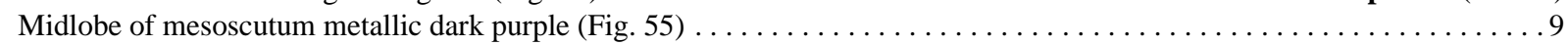

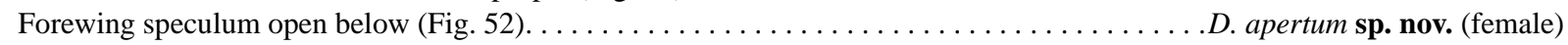

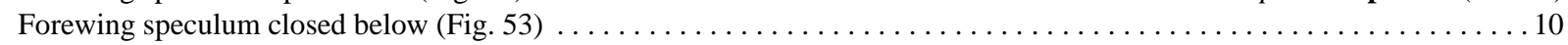

10. Female flagellum in dried specimens flattened and 1.6X as wide as pedicel (Fig. 65); clava with base of $2^{\text {nd }}$ segment distinctly narrower than apical part of $1^{\text {st }}$ segment (Fig. 65); forewing costal cell ventrally with a sparse row of setae in apical half (as in 


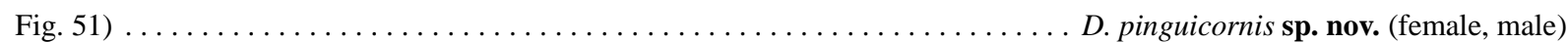
Female flagellum 1.2X as wide as pedicel (Fig. 64); clava with base of $2^{\text {nd }}$ segment almost as wide as apical part of $1^{\text {st }}$ segment (Fig. 64); forewing costal cell bare (as in Fig. 52) . . . . . . . . . . . . . . . . . . . D. noyesi sp. nov. (female)

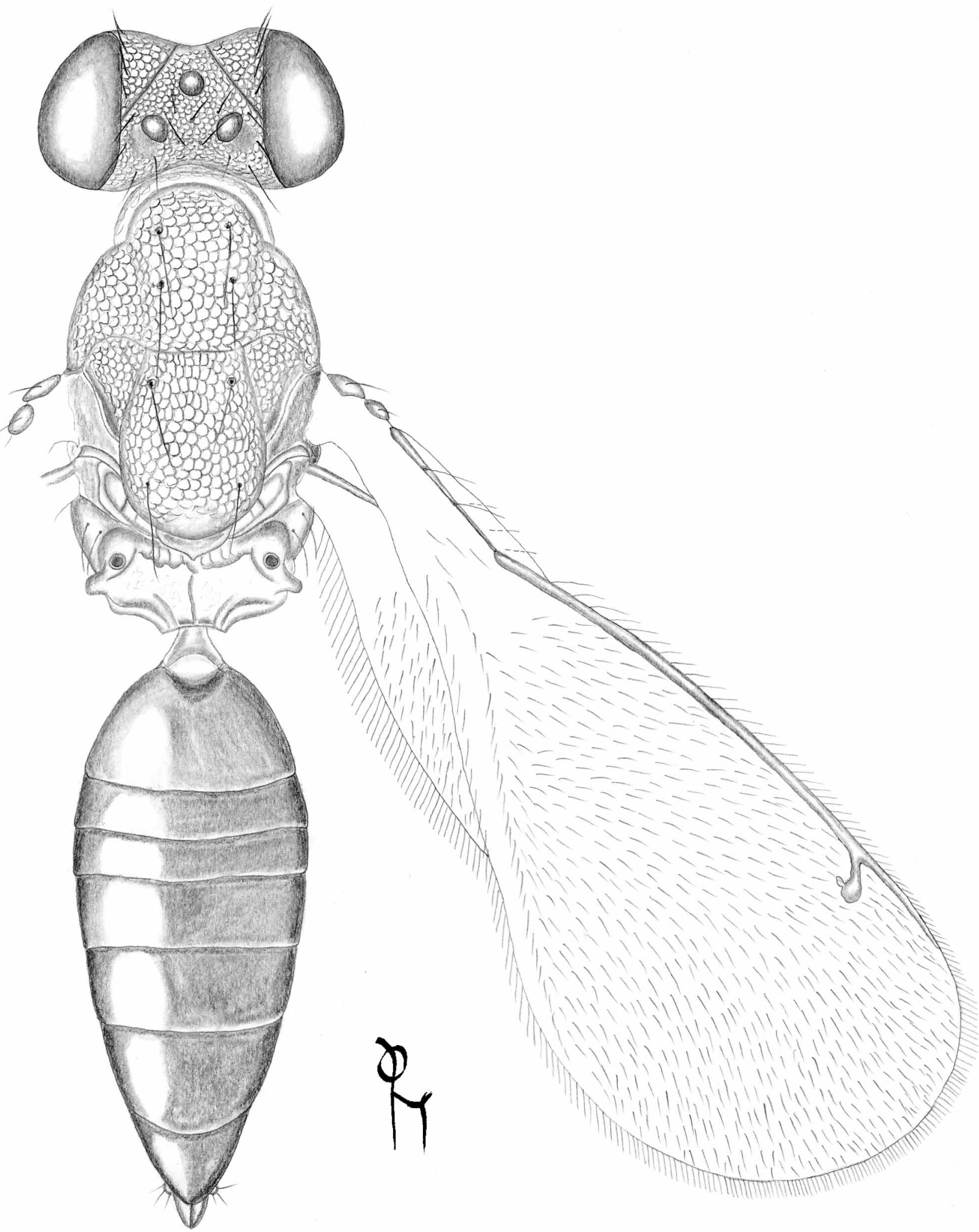

FIGURE 1. Dentalion quadrifer sp. nov., female holotype, body length $2.0 \mathrm{~mm}$. 


\section{Species treatments}

Dentalion alveum sp. nov.

(Figs 2-5, 56)

Diagnosis. Midlobe of mesoscutum with posterior $1 / 2$ smooth except for a few strong foveae (Fig. 4) and with posterior $2 / 3$ of notauli as row of pits; frontal suture reaching eyes below anterior ocellus at a distance equal to $1.5 \mathrm{X}$ diameter of an ocellus (Fig. 2); forewing costal cell bare (as in Fig. 52); propodeum smooth, callus with 4 or 5 setae.

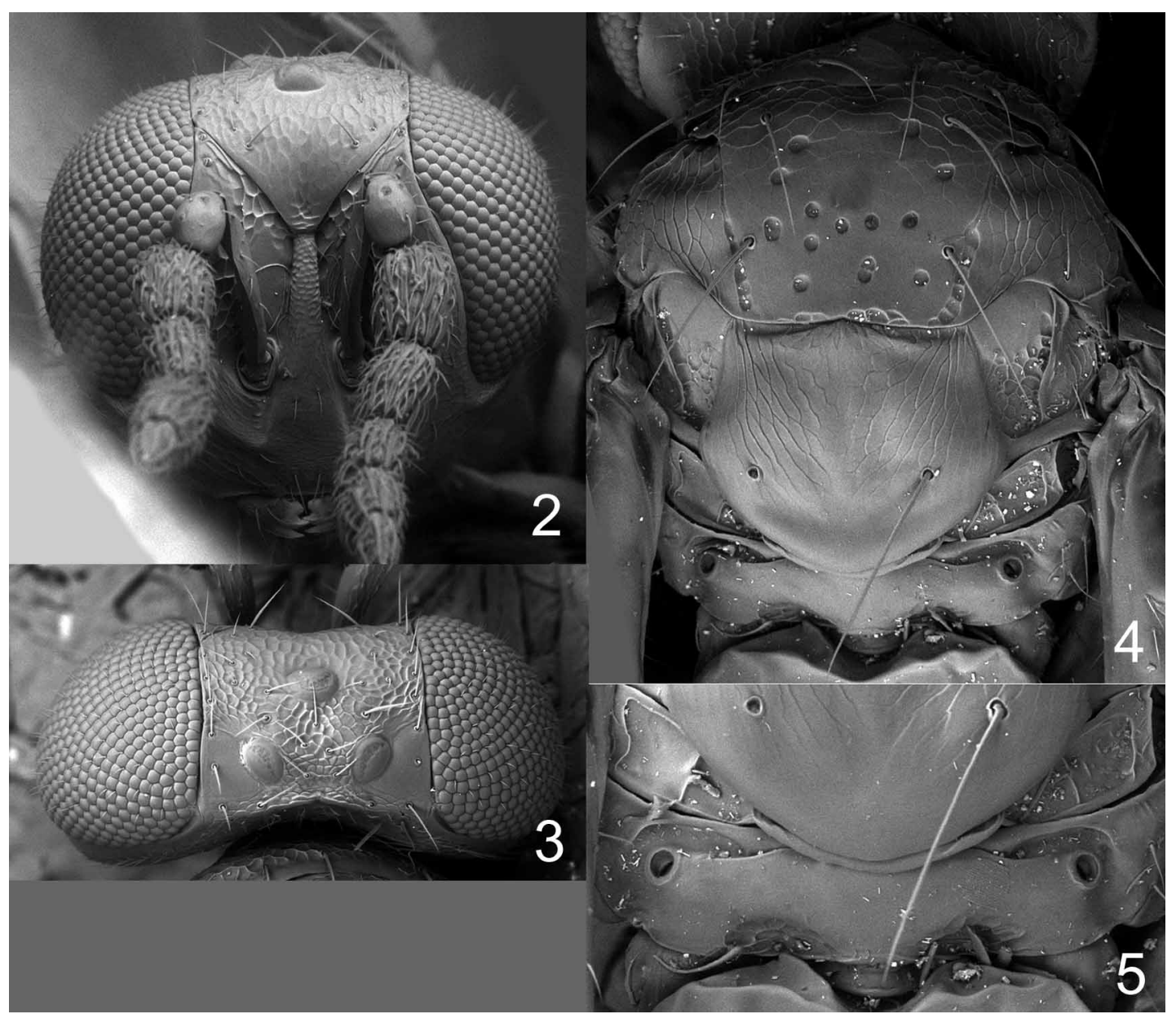

FIGURES 2-5. Dentalion alveum sp. nov., female. 2. Head frontal. 3. Head dorsal. 4. Mesosoma dorsal. 5. Propodeum dorsal.

Description. FEMALE. Length $0.8-1.7 \mathrm{~mm}$. Antenna dark brown. Frons below frontal suture golden-green; above frontal suture metallic purple. Vertex golden-green with dark brown parts inside ocellar triangle, outside dark brown. Mesoscutum metallic bluish-green. Scutellum with anterior $1 / 2$ metallic purple, posterior $1 / 2$ metallic bluish-green. Propodeum metallic bluish-purple. Coxae dark and metallic; femora and tibiae dark brown; tarsi with tarsomeres 1-3 white, 4 dark brown. Forewing hyaline. Gaster dark brown with metallic purple, blue and green tinges.

Antenna as in Fig. 56. Frons smooth below frontal suture close to scrobes and close to eyes (Fig. 2), but with raised, strong reticulation between the smooth areas and with raised, weak reticulation above frontal suture; frontal suture reaching eyes below anterior ocellus at a distance equal to $1.5 \mathrm{X}$ diameter of an ocellus. Vertex with raised, rather strong reticulation (Fig. 3) except smooth lateral to posterior ocelli. Occipital margin rounded. Eyes with sparse, scattered hairs (Figs 2, 3).

Pronotum without transverse carina close to posterior margin (Fig. 4). Mesoscutum with raised, weak reticulation (Fig. 4), midlobe with posterior $1 / 2$ smooth except for a few strong foveae; notauli as narrow distinct grooves in anterior $1 / 3$, and as row of pits in posterior 2/3. Scutellum with raised, weak reticulation (Fig. 4) except median, 
lateral, and posterior parts with very weak reticulation to smooth; with 1 pair of setae. Propodeum smooth (Fig. 5); callus with 4 or 5 setae. Forewing speculum closed below; costal cell bare.

Petiole $0.2 \mathrm{X}$ as long as wide, smooth. Gaster ovate with apex acuminate; tergites smooth.

MALE. Unknown.

Material examined. Holotype female (BMNH) labelled "COSTA RICA, Guanacaste, Parque Nacional Santa Rosa, 300 m, 14.vi-5.vii.1986, D.H. Janzen \& I.D. Gauld”. Paratypes. 2 ㅇ on cards. COSTA RICA. Guanacaste: from same locality as holotype but collected 8.ii-2.iii.1986 (1ㅇ, INBio); Puntarenas: Los Charcos de Osa, $08^{\circ} 40^{\prime} \mathrm{N} 83^{\circ} 30^{\prime} \mathrm{W}, 50 \mathrm{~m}, 15-16.1 i .2010$, J.S.Noyes (1우, BMNH).

Etymology. Named for the foveae on midlobe of mesoscutum, from the Latin alveus = pit, fovea.

Distribution. Costa Rica.

\section{Dentalion ambonatum sp. nov.}

(Figs 6-9, 57)

Diagnosis. Scutellum with 2 pairs of setae, one anterior and one posterior (Fig. 7); pronotum with a weak transverse carina close to posterior margin (Fig. 7); frontal suture reaching eyes at a level equal with anterior margin of anterior ocellus (Fig. 9); forewing costal cell ventrally with a sparse row of setae in apical 1/2 (as in Fig. 51).

Similar to D. quadrifer and D. apon except for height of frontal suture, weak pronotal carina close to posterior margin, distinct notauli in posterior 2/3 (Fig. 7), and propodeal callus with 7 setae.

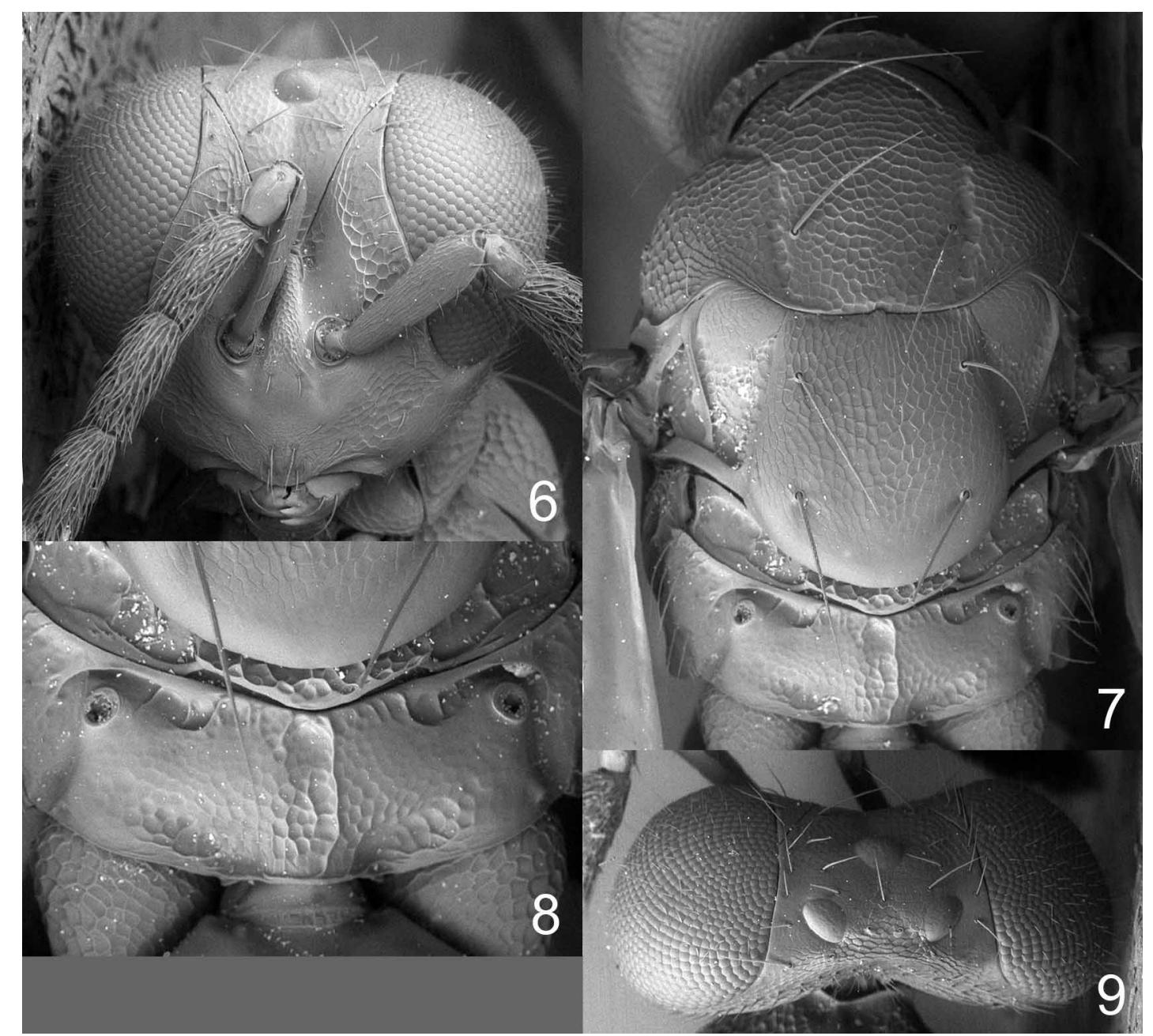

FIGURES 6-9. Dentalion ambonatum sp. nov., female. 6. Head frontal. 7. Mesosoma dorsal. 8. Propodeum dorsal. 9. Head dorsal. 
Description. FEMALE. Length $2.1 \mathrm{~mm}$. Scape pale brown with dorsal edge dark brown, pedicel and flagellum dark brown. Frons metallic bluish-purple with clypeal area golden-green. Vertex metallic bluish-purple. Mesoscutum, scutellum and propodeum metallic bluish-green with purple tinges, scutellum with posterior $1 / 5$ metallic purple. Coxae dark and metallic; femora and tibiae dark brown; tarsi with tarsomeres 1-3 white, 4 dark brown. Forewing hyaline. Gaster with tergites 1, 2, 6 metallic bluish-green, remaining tergites dark brown with metallic tinges.

Antenna as in Fig. 57. Frons with raised, weak reticulation (Fig. 6); frontal suture reaching eyes at level equal with anterior margin of anterior ocellus. Vertex with engraved, weak reticulation (Fig. 9). Occipital margin rounded. Eyes with longer hairs and eye setation denser than in other species (Figs 6, 9).

Pronotum with a weak transverse carina close to posterior margin (Fig. 7). Mesoscutum with raised, strong reticulation (Fig. 7); notauli as narrow distinct grooves in anterior $1 / 3$, and as wide but distinct grooves in posterior 2/3. Scutellum with raised, weak reticulation (Fig. 7), posterior margin smooth; with 2 pairs of setae. Propodeum with weak reticulation and irregular longitudinal carinae medially (Fig. 8); callus with 7 setae. Forewing speculum closed below; costal cell ventrally with a sparse row of setae in apical $1 / 2$.

Petiole $0.4 \mathrm{X}$ as long as wide, smooth. Gaster elongate with apex acuminate; tergites smooth.

MALE. Unknown.

Material examined. Holotype female (BMNH) labelled "BRAZIL, Bahia Mucari, xi.1978, F. Benton".

Etymology. Named for the (weak) pronotal carina, from the Greek ambon = carina, ridge.

Distribution. Brazil.

\section{Dentalion apertum sp. nov.}

(Figs 10-13, 50, 52, 58)

Diagnosis. Forewing speculum open (Fig. 52); forewing costal cell bare (Fig. 52); frontal suture reaching eyes at level equal with middle of anterior ocellus (Fig. 13); propodeum smooth (Fig. 12), callus with 5 setae.

Description. FEMALE. Length $2.3 \mathrm{~mm}$. Scape yellowish-brown with dorsal and ventral edges dark brown, pedicel and flagellum dark brown. Frons below frontal suture black with metallic blue and purple tinges, above frontal suture metallic bluish-purple. Vertex inside ocellar triangle metallic dark purple, outside ocellar triangle golden-green. Mesoscutum metallic dark purple. Scutellum with a triangular area in anterior 2/3 golden-green, otherwise metallic bluish-green. Propodeum metallic bluish-green. Coxae, femora and tibiae dark and metallic; tarsi with tarsomeres 1-3 white, 4 dark brown. Forewing hyaline. Gaster with tergites 1 and 2 metallic bluish-green, remaining tergites dark brown with golden-green tinges.

Antenna as in Fig. 58. Frons smooth below frontal suture close to scrobes and close to eyes (Fig. 10), but with raised, strong reticulation between the smooth areas and above frontal suture; frontal suture reaching eyes at level equal with middle of anterior ocellus. Vertex with raised, strong reticulation inside ocellar triangle, but smooth outside ocellar triangle (Fig. 13). Occipital margin rounded. Eyes with sparse, scattered hairs.

Pronotum without transverse carina close to posterior margin (Fig. 11). Mesoscutum with raised, strong reticulation (Fig. 11); notauli as narrow distinct grooves in anterior $1 / 3$, not visible in posterior $2 / 3$. Scutellum with raised, rather strong reticulation (Fig. 11) except posterior margin smooth; with 1 pair of setae. Propodeum smooth (Fig. 12); callus with 5 setae. Forewing speculum open below; costal cell bare.

Petiole $0.2 \mathrm{X}$ as long as wide, smooth. Gaster elongate with apex acuminate; tergites smooth.

MALE. Unknown.

Material examined. Holotype female (BMNH) labelled "COSTA RICA, Puntarenas, San Vito, Las Cruces, $08^{\circ} 47^{\prime} \mathrm{N} 82^{\circ} 58^{\prime} \mathrm{W}, 1000-1300 \mathrm{~m}, 7-19 . i i .2007$, C. Hansson".

Etymology. Named for the open speculum in the forewing, from the Latin apertus $=$ open.

Distribution. Costa Rica. 


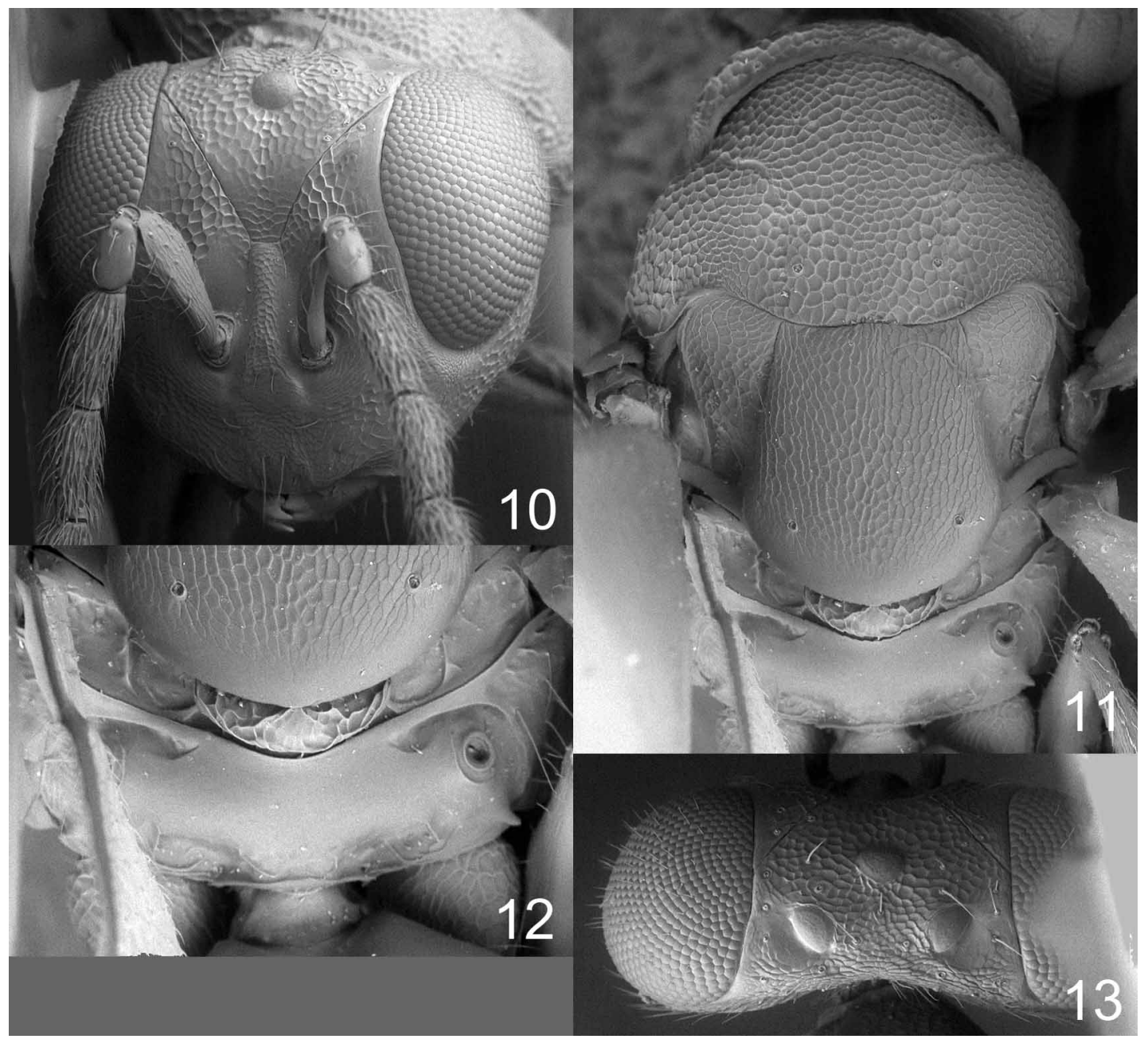

FIGURES 10-13. Dentalion apertum sp. nov., female. 10. Head frontal. 11. Mesosoma dorsal. 12. Propodeum dorsal. 13. Head dorsal.

\section{Dentalion apon sp. nov.}

(Figs 14-18, 51, 59, 60)

Diagnosis. Scutellum with 2 pairs of setae, one anterior and one posterior (Fig. 17); frontal suture reaching eyes at a level equal to half distance between posterior margin of anterior ocellus and anterior margin of posterior ocelli (Fig. 15); forewing costal cell ventrally with a sparse row of setae in apical $1 / 2$ (Fig. 51).

Similar to D. quadrifer except frons and vertex with much weaker reticulation (Figs 14, 15) and mesoscutum and scutellum with distinctly larger meshes (Fig. 17).

Description. FEMALE. Length $1.4 \mathrm{~mm}$. Scape yellowish-brown with dorsal edge dark brown, pedicel and flagellum dark brown. Frons metallic purple. Vertex golden-green. Mesoscutum, scutellum and propodeum metallic bluish-green. Coxae dark and metallic; femora and tibiae dark brown; tarsi with tarsomeres 1-3 white, 4 dark brown. Forewing hyaline. Gaster with tergites 1 and 2 metallic bluish-purple, remaining tergites dark brown with metallic tinges.

Antenna as in Fig. 59. Frons with raised, weak reticulation (Fig. 14); frontal suture reaching eyes at a level equal to half distance between posterior margin of anterior ocellus and anterior margin of posterior ocelli. Vertex with engraved, weak reticulation (Fig. 16). Occipital margin rounded. Eyes with sparse, scattered hairs (Figs 1416).

Pronotum without transverse carina close to posterior margin (Fig. 17). Mesoscutum with raised, strong reticulation (Fig. 17); notauli as narrow distinct grooves in anterior $1 / 3$, not visible in posterior $2 / 3$. Scutellum with 
raised, strong reticulation (Fig. 17); with 2 pairs of setae. Propodeum smooth except for irregular longitudinal carinae medially (Fig. 18); callus with 2 setae. Forewing speculum closed below; costal cell ventrally with a sparse row of setae in apical $1 / 2$.

Petiole 0.4X as long as wide, smooth. Gaster elongate with apex acuminate; tergites smooth.

MALE. Length $1.4 \mathrm{~mm}$. Colour as in female. Antenna as in Fig. 60; head otherwise as in female (Fig. 16). Mesosoma and metasoma as in female.

Material examined. Holotype female (INBio) labelled "COSTA RICA, Guanacaste, A.C.T. Bagaces, Parque Nacional Palo Verde, Sct Palo Verde, Extremo E de campo de Aterrizaje, 50 m, 9.xii.1999-5.i.2000, I. Jiménez, LN 260952/385020, \#54957". Paratype. $10^{x}$ on card. COSTA RICA: Guanacaste, from same locality as holotype but collected 9.ii-12.iii.2001 (INBio).

Etymology. No specific meaning intended.

Distribution. Costa Rica.

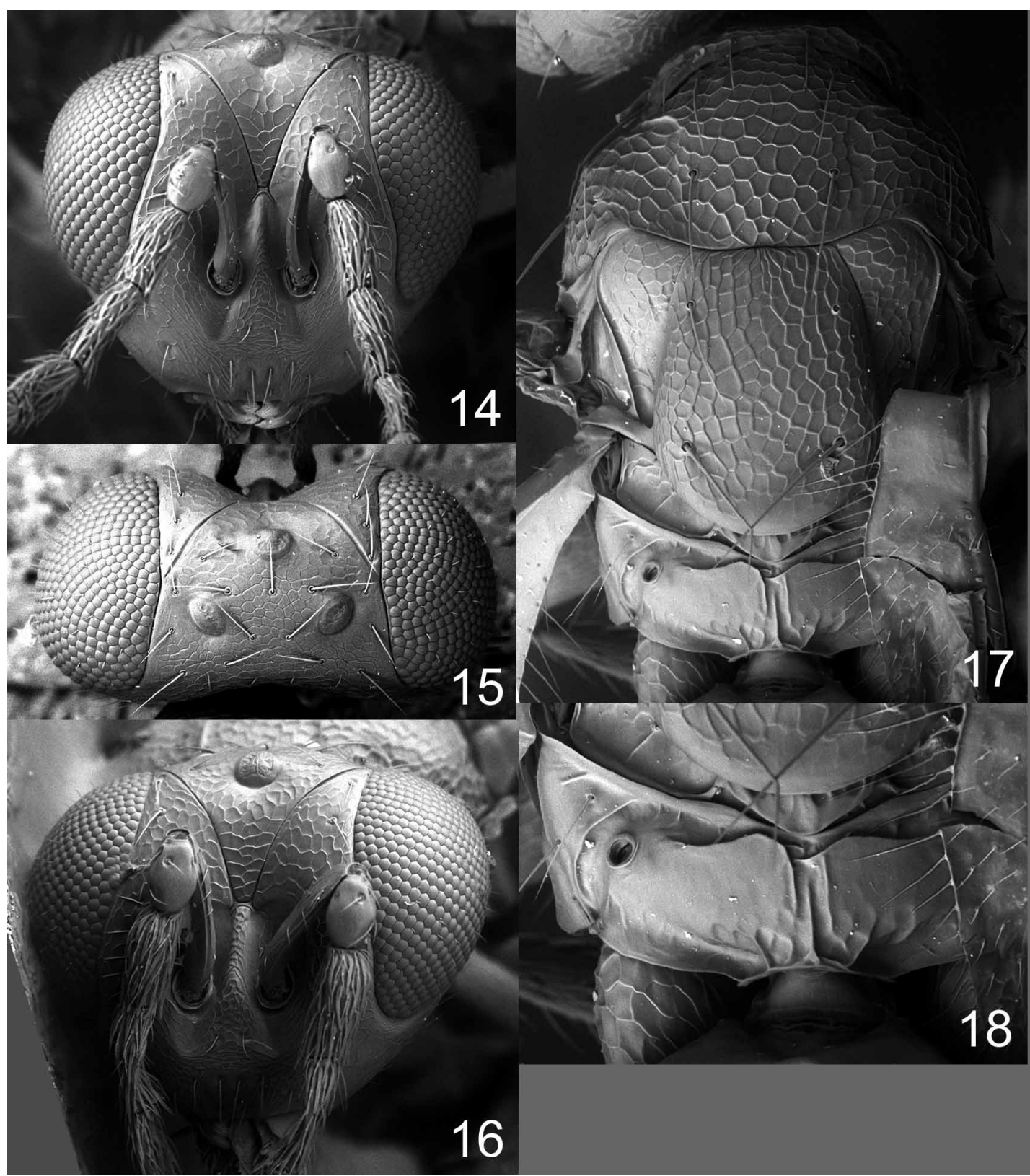

FIGURES 14-18. Dentalion apon sp. nov. 14. Head frontal, female. 15. Head dorsal, female. 16. Head frontal, male. 17. Mesosoma dorsal, female. 18. Propodeum dorsal, female. 


\section{Dentalion crassicornis sp. nov.}

(Figs 19-22, 54, 61)

Diagnosis. Flagellum thick, second flagellomere 1.7X as wide as pedicel (Fig. 61); frontal suture reaching eyes at level equal with anterior margin of anterior ocellus (Fig. 19); thoracic dorsum golden-green (Fig. 54); forewing costal cell bare (as in Fig. 52); propodeum smooth (Fig. 22), callus with 7 setae.

Description. FEMALE. Length $1.9 \mathrm{~mm}$. Scape yellowish-brown with dorsal edge dark brown, pedicel and flagellum dark brown. Frons below frontal suture metallic bluish-purple, above frontal suture metallic bluish-green. Vertex golden-green. Mesoscutum, scutellum and propodeum golden-green. Coxae dark and metallic; femora and tibiae dark brown; tarsi with tarsomeres 1-3 white, 4 dark brown. Forewing hyaline. Gaster golden-green.

Antenna as in Fig. 61. Frons with raised, strong reticulation below frontal suture and raised, very weak reticulation above frontal suture (Fig. 19); frontal suture reaching eyes at level equal with anterior margin of anterior ocellus. Vertex with engraved, weak reticulation inside ocellar triangle except medially with raised, strong reticulation, and smooth outside ocellar triangle (Fig. 20). Occipital margin rounded. Eyes with sparse, scattered hairs (Figs 19, 20).

Pronotum without transverse carina close to posterior margin (Fig. 21). Mesoscutum with raised, rather strong reticulation (Fig. 21); notauli as narrow distinct grooves in anterior $1 / 3$, as a row of pits in posterior $2 / 3$. Scutellum with raised, weak reticulation except posterior margin smooth (Fig. 21); with 1 pair of setae. Propodeum smooth (Fig. 22); callus with 7 setae. Forewing speculum closed below; costal cell bare.

Petiole $0.2 \mathrm{X}$ as long as wide, smooth. Gaster elongate with apex acuminate; tergites smooth.

MALE. Unknown.

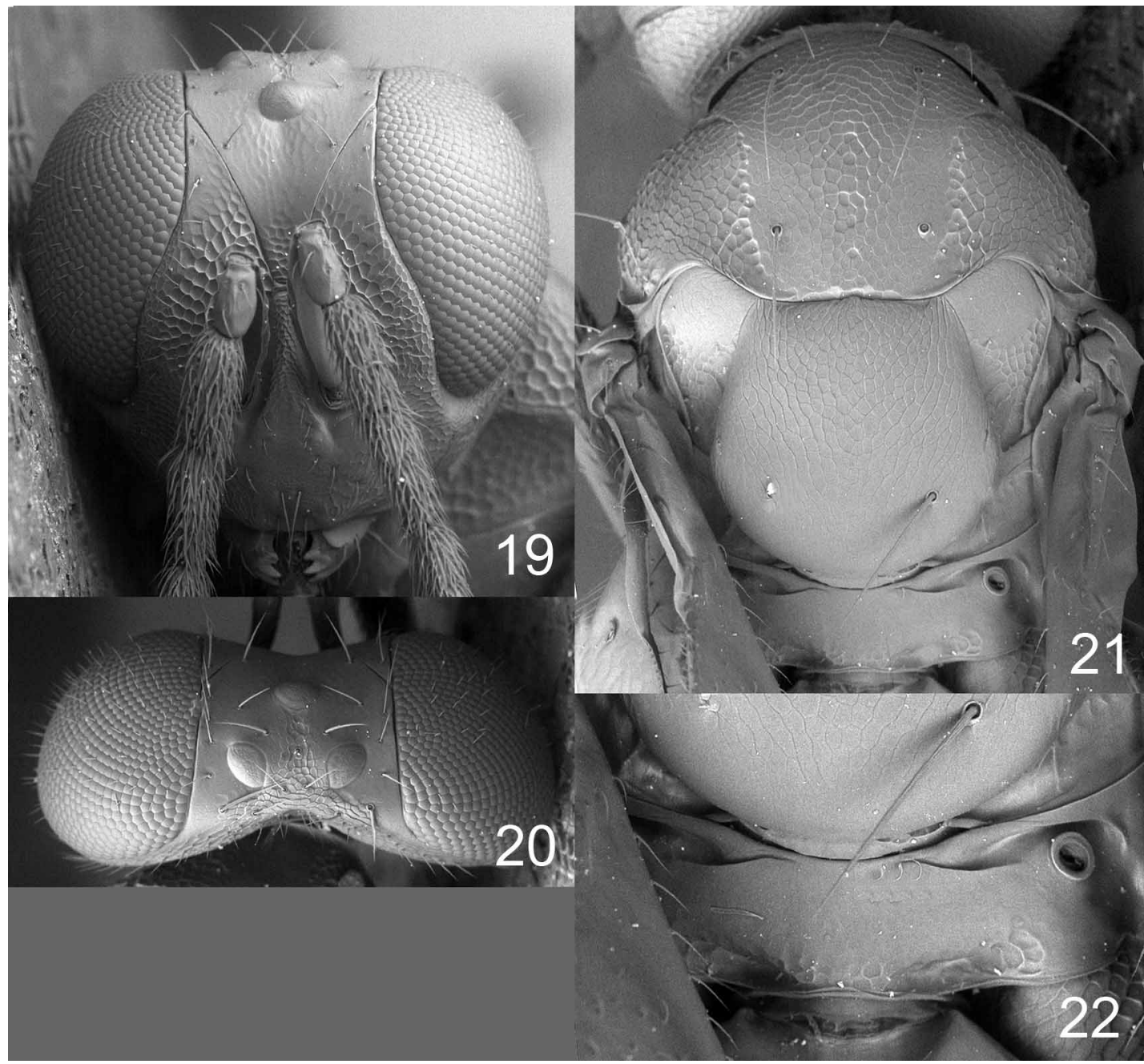

FIGURES 19-22. Dentalion crassicornis sp. nov., female. 19. Head frontal. 20. Head dorsal. 21. Mesosoma dorsal. 22. Propodeum dorsal. 
Material examined. Holotype female (BMNH) labelled "TRINIDAD, St. George, St. Augustine, xii.1976, F.D. Bennett".

Etymology. Named for the thick flagellum of the antenna, from the Latin crassus $=$ thick, and cornu $=$ horn.

Distribution. Trinidad \& Tobago.

\section{Dentalion jimenezi sp. nov.}

(Figs 23-26, 62, 64)

Diagnosis. Frontal suture reaching eyes at a level equal to half distance between posterior margin of anterior ocellus and anterior margin of posterior ocelli (Fig. 26); forewing costal cell bare (as in Fig. 52); propodeum smooth (Fig. 25), callus with 2 setae.

Description. FEMALE. Length 1.6-1.8 mm. Scape yellowish-brown with dorsal edge dark brown, pedicel and flagellum dark brown. Frons metallic bluish-purple. Vertex black with metallic bluish-purple tinges. Mesoscutum with anterior $1 / 2$ black with metallic tinges, posterior $1 / 2$ metallic bluish-green. Scutellum with anterior $3 / 4$ goldenpurple, posterior $1 / 4$ metallic bluish-purple. Propodeum metallic bluish-green. Coxae dark and metallic; femora and tibiae dark brown; fore tarsus with tarsomeres 1-3 white, 4 dark brown, mid and hind tarsi completely white. Forewing hyaline. Gaster with tergites 1 and 6 metallic bluish-purple, remaining tergites dark brown with metallic tinges.

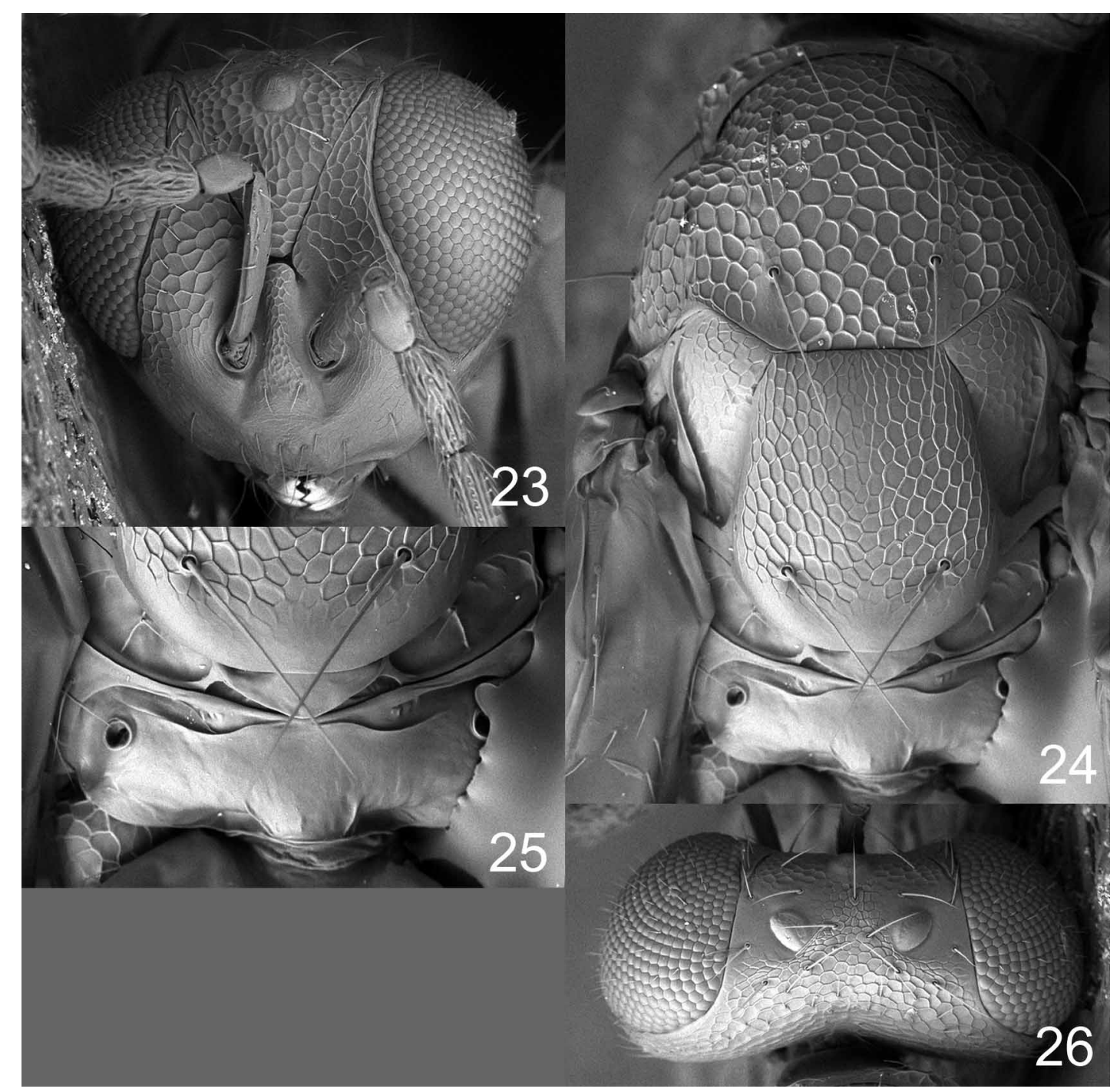

FIGURES 23-26. Dentalion jimenezi sp. nov., female. 23. Head frontal. 24. Mesosoma dorsal. 25. Propodeum dorsal. 26. Head dorsal. 
Antenna as in Fig. 62. Frons with raised, strong reticulation (Fig. 23); frontal suture reaching eyes at a level equal to half distance between posterior margin of anterior ocellus and anterior margin of posterior ocelli. Vertex with engraved, strong reticulation inside ocellar triangle, but smooth outside ocellar triangle (Fig. 26). Occipital margin rounded. Eyes with sparse, scattered hairs (Figs 23, 26).

Pronotum without transverse carina close to posterior margin (Fig. 24). Mesoscutum with raised, strong reticulation (Fig. 24); notauli as narrow distinct grooves in anterior $1 / 3$, not visible in posterior $2 / 3$. Scutellum with raised, rather strong reticulation in anterior $3 / 4$, but posterior $1 / 4$ smooth (Fig. 24); with 1 pair of setae. Propodeum smooth (Fig. 25); callus with 2 setae. Forewing speculum closed below; costal cell bare.

Petiole $0.2 \mathrm{X}$ as long as wide, smooth. Gaster elongate with apex acuminate; tergites smooth.

MALE. Length 1.3-1.4 mm. Scape yellowish-brown to pale brown, with dorsal edge dark brown. Mesoscutum metallic bluish-green. Gaster with a large white spot in anterior $1 / 2$. Colour otherwise as in female. Antenna as in Fig. 64; head otherwise as in female. Mesosoma and metasoma as in female.

Material examined. Holotype female (INBio) labelled "COSTA RICA, Guanacaste, Bagaces, P.N. Palo Verde, Sct Palo Verde, Extremo E de campo de Aterrizaje, 10 m, 10.i-9.ii.2001, I. Jiménez, LN 259050/388400,

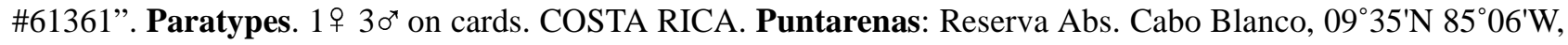
30 m, 16-17.ii.2009, J.S. Noyes (BMNH).

Etymology. Named after the collector of the holotype, Iván Jiménez, former parataxonomist at INBio.

Distribution. Costa Rica.

\section{Dentalion mischum sp. nov.}

(Figs 27-30, 63)

Diagnosis. Propodeum with plicae and with an irregular carina between plicae (Fig. 29), callus with 8 setae; petiole $1.8 \mathrm{X}$ as long as wide (Fig. 29); frontal suture reaching eyes at level equal with anterior margin of anterior ocellus (Fig. 30); forewing costal cell ventrally with a row of setae in apical $1 / 2$ (as in Fig. 51).

Description. FEMALE. Length $3.0 \mathrm{~mm}$. Scape with dorsal $1 / 2$ dark brown, ventral $1 / 2$ yellowish-brown, pedicel and flagellum dark brown. Frons metallic bluish-purple. Vertex metallic bluish-green. Mesoscutum, scutellum and propodeum metallic bluish-green. Coxae, femora and tibiae dark brown; tarsi with tarsomeres 1-3 white, 4 dark brown. Forewing hyaline. Gaster with tergites 1and 2 metallic bluish-green with purple tinges, remaining tergites dark brown with metallic tinges.

Antenna as in Fig. 63. Frons with raised, weak reticulation below level of toruli except smooth just below toruli and just below eyes, parts up to frontal suture and in angle just above frontal suture with raised, strong reticulation, and otherwise smooth above frontal suture (Fig. 27); frontal suture reaching eyes at level equal with anterior margin of anterior ocellus. Vertex with engraved, strong reticulation inside ocellar triangle, but smooth outside ocellar triangle (Fig. 30). Occipital margin rounded. Eyes with sparse, scattered hairs (Figs 27, 30).

Pronotum without transverse carina close to posterior margin (Fig. 28). Mesoscutum with raised, strong reticulation (Fig. 28); notauli as narrow distinct grooves in anterior $1 / 3$, not visible in posterior $2 / 3$. Scutellum with raised, rather strong reticulation except posterior and lateral margins smooth (Fig. 28); with 1 pair of setae. Propodeum with plicae and with irregular carinae between plicae (Fig. 29); callus with 8 setae. Forewing speculum closed below; forewing costal cell ventrally with a row of setae in apical $1 / 2$.

Petiole 1.8X as long as wide, dorsal surface with very weak sculpture (Fig. 29). Gaster elongate with apex acuminate; tergites smooth.

MALE. Unknown.

Material examined. Holotype female (LUZM) labelled "ECUADOR, Pichin, Nono-Tandayapa road, 1900 m, 27.ii.1983, L. Huggert".

Etymology. Named for the elongate petiole, from the Greek mischos = stalk, petiole.

Distribution. Ecuador. 


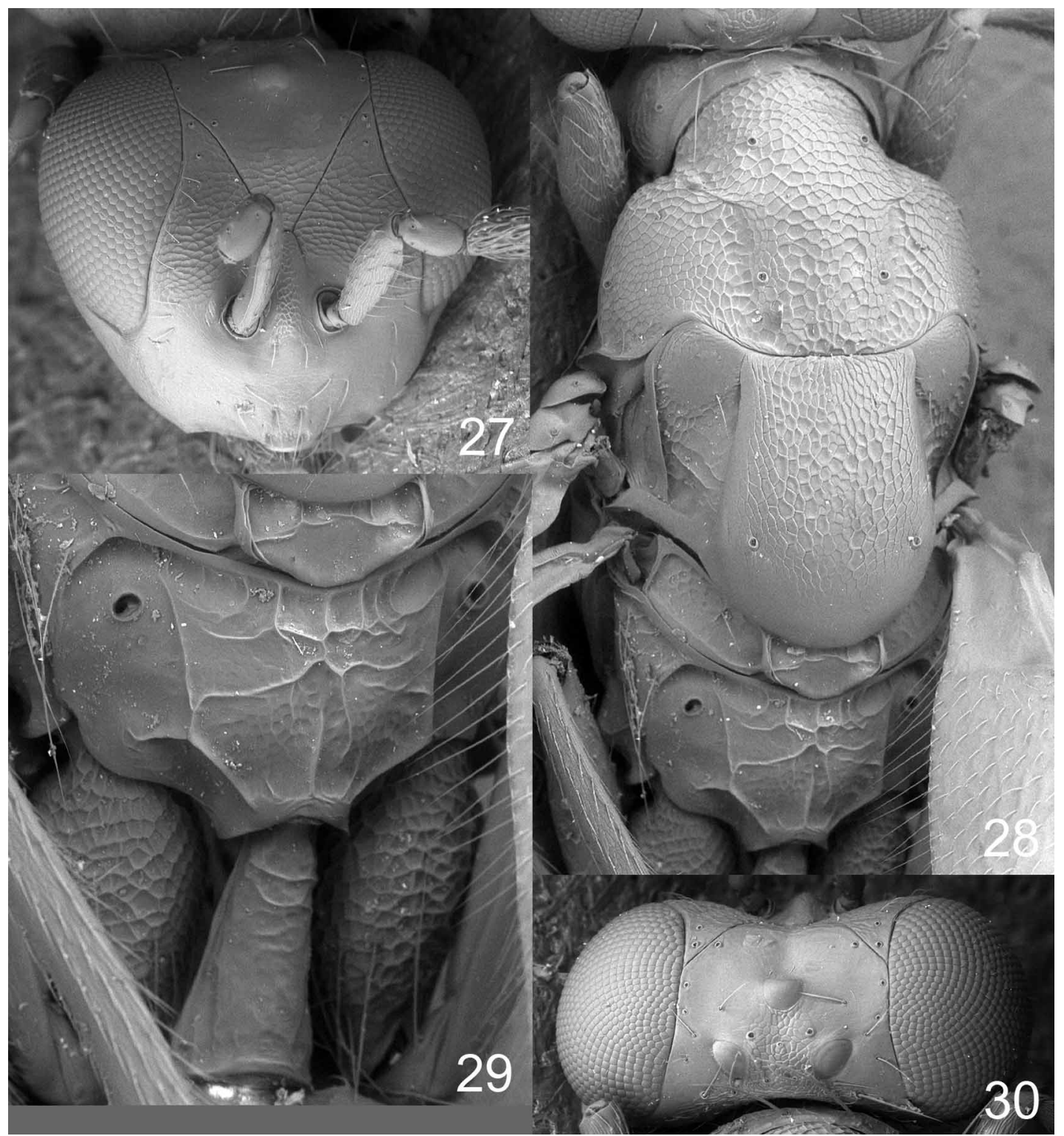

FIGURES 27-30. Dentalion mischum sp. nov., female. 27. Head frontal. 28. Mesosoma dorsal. 29. Propodeum and petiole dorsal. 30. Head dorsal.

\section{Dentalion noyesi sp. nov.}

(Figs 31-34, 49, 53, 66)

Diagnosis. Frontal suture reaching eyes at level equal with anterior margin of anterior ocellus (Fig. 34); forewing costal cell bare (Fig. 53); propodeum smooth (Fig. 33), callus with 6 setae.

Description. FEMALE. Length 1.4-2.0 mm. Scape yellowish-brown with dorsal and ventral edges dark brown, pedicel and flagellum dark brown. Frons metallic purple. Vertex inside ocellar triangle golden-purple, outside ocellar triangle metallic bluish-green. Mesoscutum metallic bluish-green with posterior $1 / 2$ of midlobe metallic dark purple. Scutellum metallic bluish-green, with purple tinges in posterior $1 / 4$. Propodeum metallic bluish-green. Coxae dark and metallic; femora and tibiae dark brown; mid tarsus completely white, fore and hind tarsi with tarsomeres 1-3 white, 4 dark brown. Forewing hyaline. Gaster with tergites 1 and 6 metallic bluish-green, tergites 25 with anterior $1 / 2$ metallic bluish-green and posterior $1 / 2$ golden-purple, tergite 7 golden-purple.

Antenna as in Fig. 66. Frons with raised, strong reticulation below frontal suture and with very weak reticulation above frontal suture (Fig. 31); frontal suture reaching eyes at level equal with anterior margin of anterior ocel- 
lus. Vertex with engraved, strong reticulation inside ocellar triangle, but smooth outside ocellar triangle (Fig. 34). Occipital margin rounded. Eyes with sparse, scattered hairs (Figs 31, 34).

Pronotum without transverse carina close to posterior margin (Fig. 32). Mesoscutum with raised, strong reticulation (Fig. 32); notauli as narrow distinct grooves in anterior 1/3, indistinct in posterior $2 / 3$. Scutellum with raised, rather weak reticulation except posterior margin smooth (Fig. 32); with 1 pair of setae. Propodeum smooth (Fig. 33); callus with 6 setae. Forewing speculum closed below; costal cell bare.

Petiole $0.2 \mathrm{X}$ as long as wide, smooth. Gaster elongate with apex acuminate; tergites smooth.

MALE. Unknown.

Material examined. Holotype female (BMNH) labelled "COSTA RICA, Puntarenas, Reserva Privada Karen Mogensen, $09^{\circ} 52^{\prime} \mathrm{N} 85^{\circ} 03^{\prime} \mathrm{W}, 305$ m, 14-15.ii.2005, J.S. Noyes". Paratypes. 2 우 on cards. COSTA RICA. Puntarenas: from same locality as holotype but collected 18.iii-4.iv.2003 (1ㅇ, INBio). TRINIDAD \& TOBAGO. Curepe, 9.vi.1978, malaise trap (1ㅇ, CNC).

Etymology. Named after the collector of the holotype, John S. Noyes, Scientific Associate of the Entomology Department of the Natural History Museum in London.

Distribution. Costa Rica, Trinidad \& Tobago.

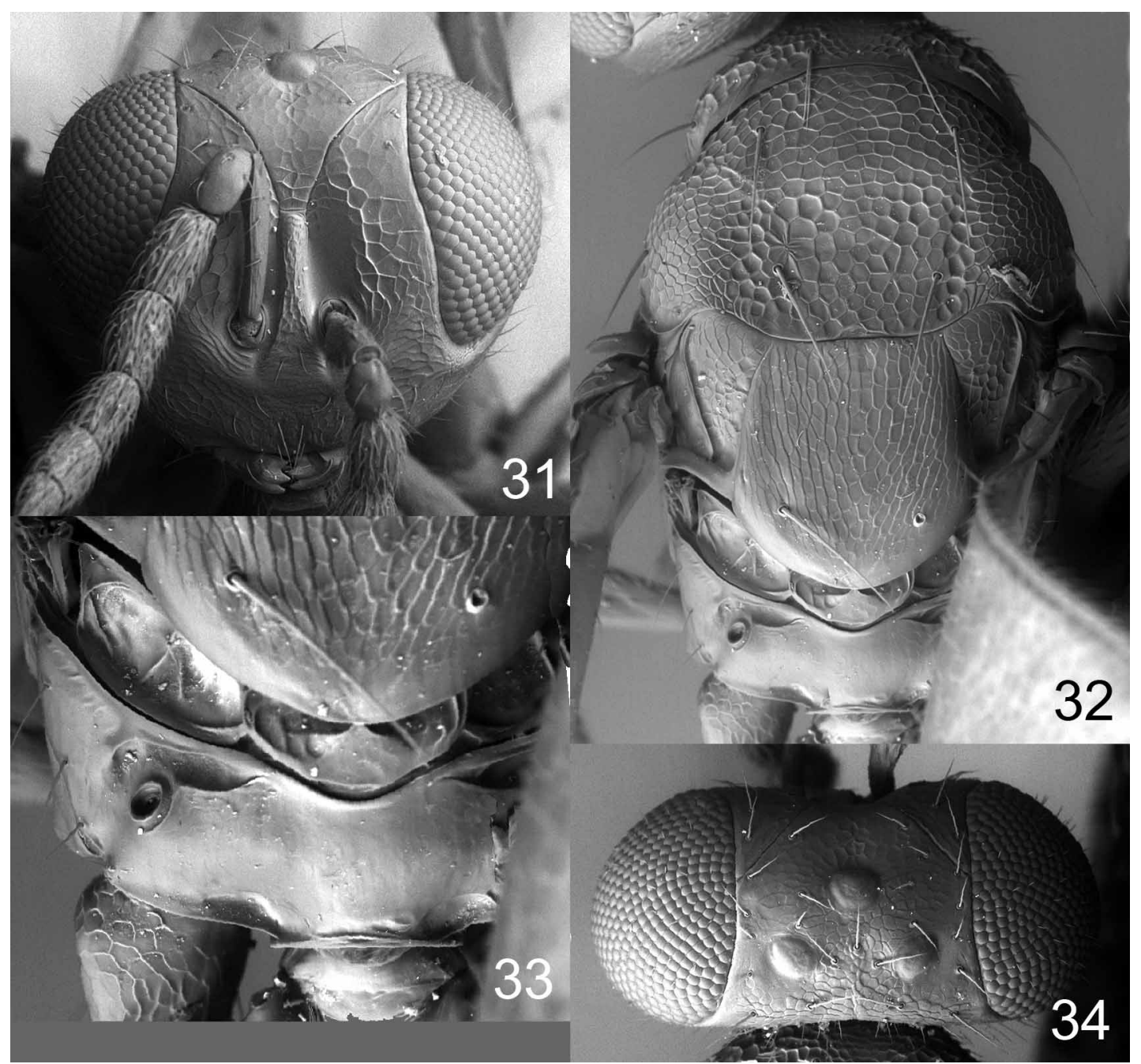

FIGURES 31-34. Dentalion noyesi sp. nov., female. 31. Head frontal. 32. Mesosoma dorsal. 33. Propodeum dorsal. 34. Head dorsal.

\section{Dentalion pinguicornis sp. nov.}

(Figs 35-38, 47, 48, 55, 65, 67)

Diagnosis. Flagellum thick, second flagellomere 1.9X as wide as pedicel (Fig. 65); frontal suture reaching eyes at level equal with anterior margin of anterior ocellus (Fig. 35); forewing costal cell ventrally with a sparse row of 
setae in apical 1/2 (as in Fig. 51); propodeum with irregular sculpture medially or completely smooth (Fig. 38), propodeal callus with 5 setae.

Description. FEMALE. Length 1.9-2.4 mm. Scape dark brown with basal 2/3 of outer surface yellowishbrown, pedicel and flagellum dark brown. Frons below level of toruli black with green and blue tinges, between level of toruli and frontal suture metallic purple, above frontal suture metallic bluish-purple. Vertex inside ocellar triangle golden-purple, outside ocellar triangle metallic bluish-purple. Mesoscutum golden-purple, lateral parts of sidelobes metallic bluish-purple. Scutellum metallic bluish-green, with purple tinges in posterior $1 / 4$. Propodeum metallic bluish-green, medially with purple tinges. Coxae dark and metallic; femora and tibiae dark brown; mid tarsus completely white, fore and hind tarsi with tarsomeres 1-3 white, 4 dark brown. Forewing hyaline. Gaster with tergite 1 metallic bluish-green, tergite 2 metallic bluish-purple, remaining tergites golden-purple.

Antenna as in Fig. 65. Frons with weak reticulation below level of toruli except smooth just below toruli, but with raised, strong reticulation between toruli and frontal suture, and smooth or with very weak reticulation above frontal suture (Fig. 35); frontal suture reaching eyes at level equal with anterior margin of anterior ocellus. Vertex with engraved, strong reticulation inside ocellar triangle, but smooth outside ocellar triangle (Fig. 36). Occipital margin rounded. Eyes with sparse, scattered hairs (Figs 35, 36).

Pronotum without transverse carina close to posterior margin (Fig. 37). Mesoscutum with raised, strong reticulation (Fig. 37); notauli as narrow distinct grooves in anterior $1 / 3$, as wide impressions in posterior $2 / 3$. Scutellum with raised, rather strong reticulation in anterior $2 / 3$ (Fig. 37) and posterior $1 / 3$ with very weak reticulation except posterior margin smooth; with 1 pair of setae. Propodeum completely smooth or with irregular sculpture in median part (Fig. 38); callus with 5 setae. Forewing speculum closed below; forewing costal cell ventrally with a sparse row of setae in apical $1 / 2$.

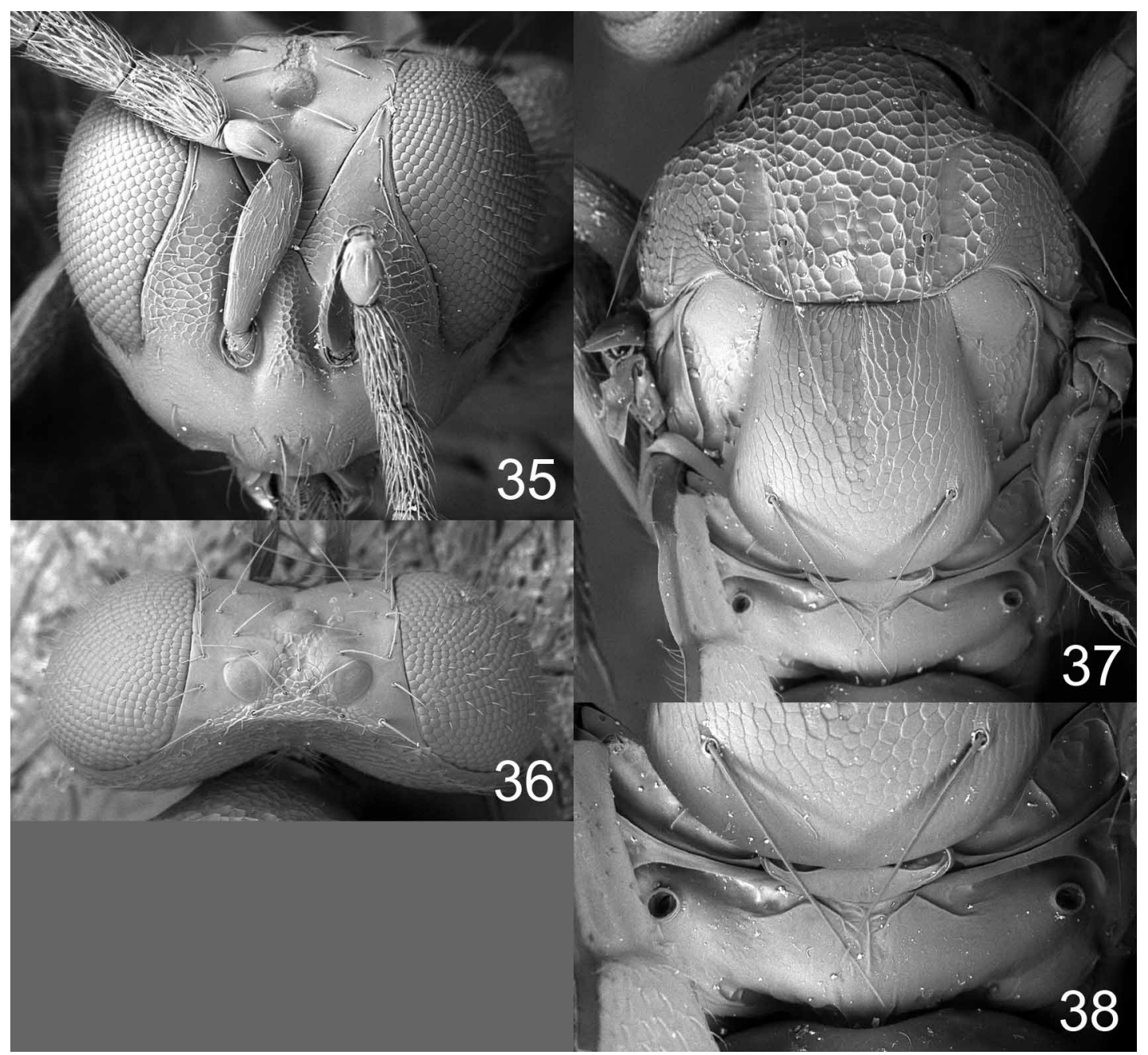

FIGURES 35-38. Dentalion pinguicornis sp. nov., female. 35. Head frontal. 36. Head dorsal. 37. Mesosoma dorsal. 38. Propodeum dorsal. 
Petiole $0.2 \mathrm{X}$ as long as wide, smooth. Gaster ovate with apex acuminate; tergites smooth.

MALE. Length $2.2 \mathrm{~mm}$. Gaster with anteromedian $1 / 2$ with a white spot. Colour otherwise as in female. Antenna as in Fig. 67; head otherwise as in female. Mesosoma as in female.

Material examined. Holotype female (BMNH) labelled "COSTA RICA, Guanacaste, Area de Conservación de Guanacaste, Estación Cacao, 1500 m, 19-20.ii.2005, J.S. Noyes”. Paratypes. 2 우 $10^{\star}$ on cards. COSTA RICA. Guanacaste: with same label data as holotype $\left(10^{x}, \mathrm{BMNH}\right)$. Puntarenas: Estación Altamira, Sendero Los

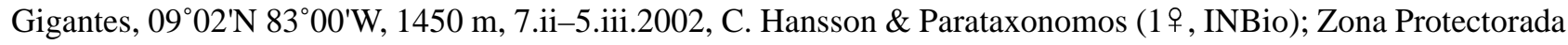
Peninsula de Nicoya, Reserva Privada Karen Mogensen, Sendero Mirador, LN 205300/421100, 420 m, 14.iii.2002, I. Jiménez (1오 INBio).

Etymology. Named for the thick female flagellum, from the Latin pinguis $=$ fat, and cornu $=$ horn.

Distribution. Costa Rica.

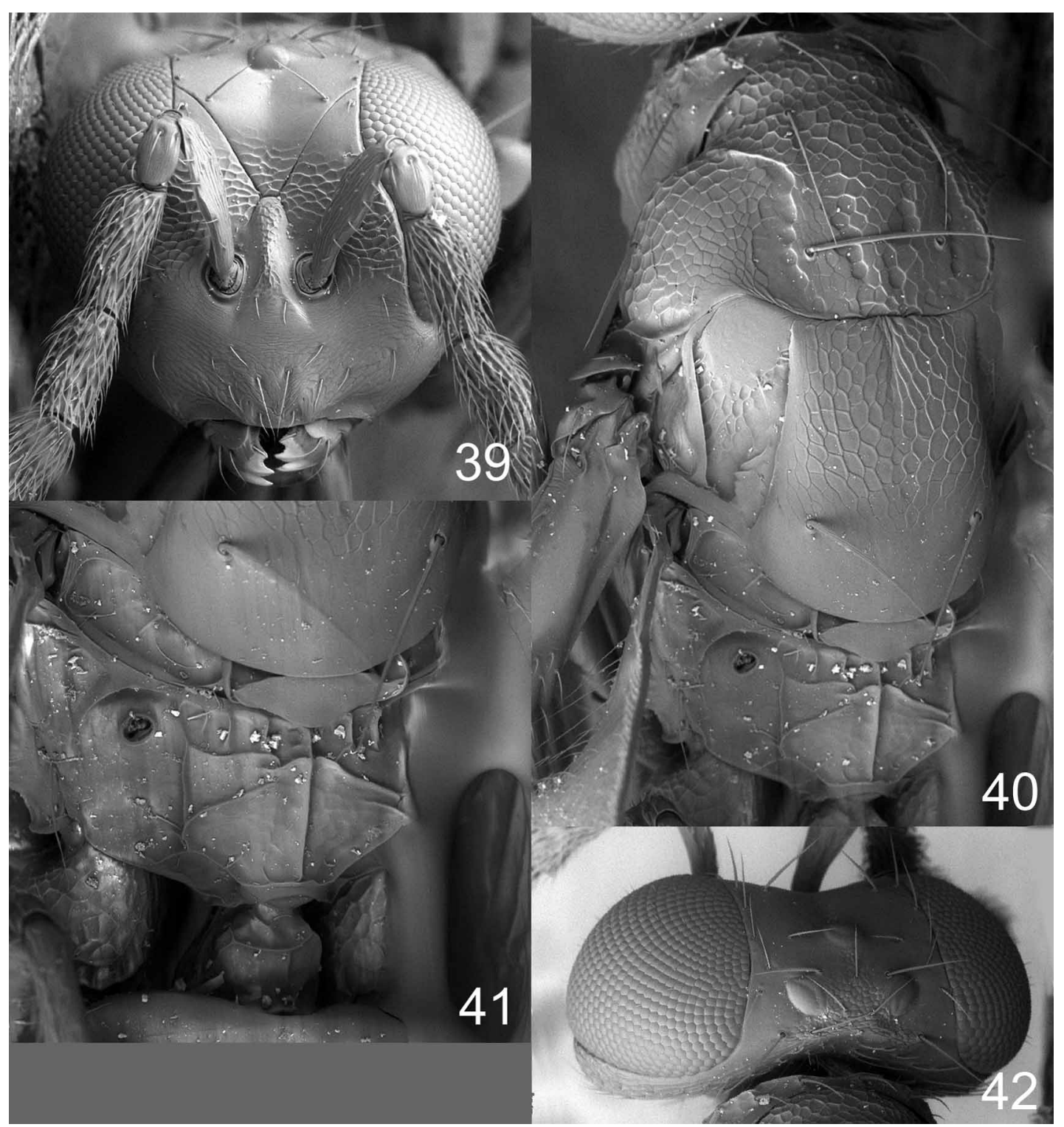

FIGURES 39-42. Dentalion pnigaliae sp. nov., female. 39. Head frontal. 40. Mesosoma dorsal. 41. Propodeum dorsal. 42. Head dorsal.

\section{Dentalion pnigaliae sp. nov.}

(Figs 39-42, 68)

Diagnosis. Frons with an interscrobal procession (Fig. 39); frontal suture reaching eyes below anterior ocellus at a level equal to 1.5X diameter of an ocellus (Fig. 39); propodeum with median carina, plicae and costulae (Fig. 41), 
and callus with 6 setae; forewing costal cell ventrally with a sparse row of setae in apical 1/2 (as in Fig. 51); petiole as long as wide.

Description. FEMALE. Length $1.9 \mathrm{~mm}$. Scape pale brown with dorsal edge dark brown, pedicel and flagellum dark brown. Frons below frontal suture metallic bluish-green, above frontal suture metallic bluish-purple. Vertex inside ocellar triangle golden-green, outside ocellar triangle metallic bluish-purple. Mesoscutum with anterior 1/3 metallic dark purple, posterior $2 / 3$ metallic bluish-green. Scutellum with anterior $1 / 2$ golden-purple, posterior $1 / 2$ metallic bluish-green. Propodeum metallic bluish-green. Coxae, femora and tibiae dark and metallic; tarsi with tarsomeres 1-3 white, 4 dark brown. Forewing hyaline. Gaster with tergite 1 metallic bluish-purple, remaining tergites golden-purple.

Antenna as in Fig. 68. Frons with raised, weak reticulation below level of toruli except smooth just below toruli and close to mouth margin above mandibles, parts up to frontal suture with raised, strong reticulation, and smooth above frontal suture (Fig. 39); frontal suture reaching eyes below anterior ocellus at a level equal to 1.5X diameter of an ocellus. Vertex with engraved, strong reticulation inside ocellar triangle, but smooth outside ocellar triangle (Fig. 42). Occipital margin rounded. Eyes with sparse, scattered hairs (Figs 39, 42).

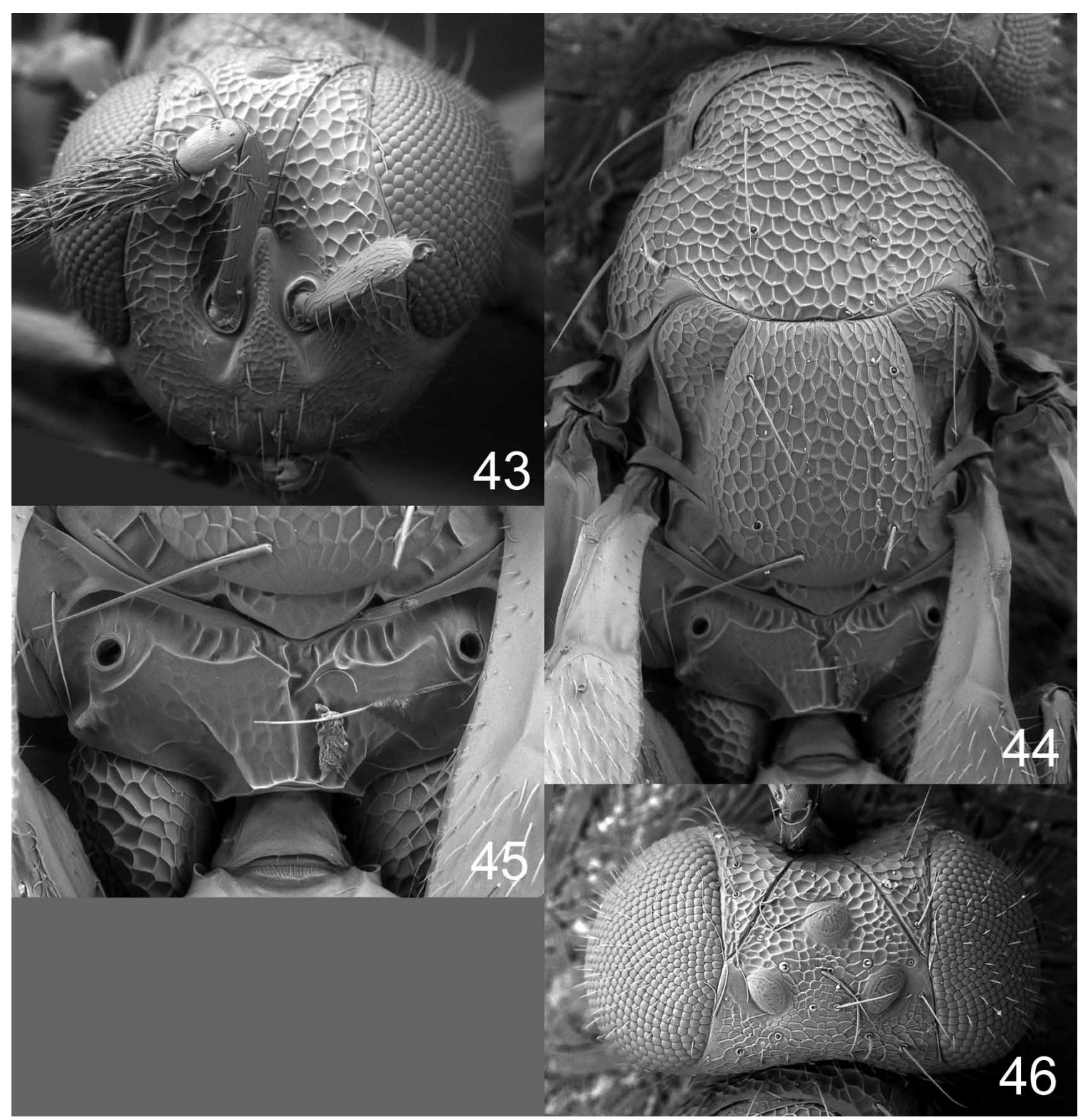

FIGURES 43-46. Dentalion quadrifer sp. nov., female. 43. Head frontal. 44. Mesosoma dorsal. 45. Propodeum dorsal. 46. Head dorsal. 
Pronotum without transverse carina close to posterior margin (Fig. 40). Mesoscutum with raised, strong reticulation (Fig. 40); notauli as narrow distinct grooves in anterior $1 / 3$, as indistinct impressions in posterior $2 / 3$. Scutellum with raised, rather strong reticulation in anterior $1 / 2$ and very weak reticulation to smooth in posterior $1 / 2$ (Fig. 40); with 1 pair of setae. Propodeum with median carina, plicae and costulae (Fig. 41); callus with 6 setae. Forewing speculum closed below; forewing costal cell ventrally with a sparse row of setae in apical 1/2.

Petiole $1 \mathrm{X}$ as long as wide, smooth. Gaster elongate with apex acuminate; tergites smooth.

MALE. Unknown.

Material examined. Holotype female (BMNH) labelled "COSTA RICA, Heredia, Estación Biológica La Selva, $10^{\circ} 26^{\prime} \mathrm{N} 84^{\circ} 01^{\prime} \mathrm{W}, 75 \mathrm{~m}, 27-28 . i i .2003$, J.S. Noyes".

Etymology. Named for the similarity of the propodeum in the genus Pnigalio Schrank (subfamily Eulophinae).

Distribution. Costa Rica.

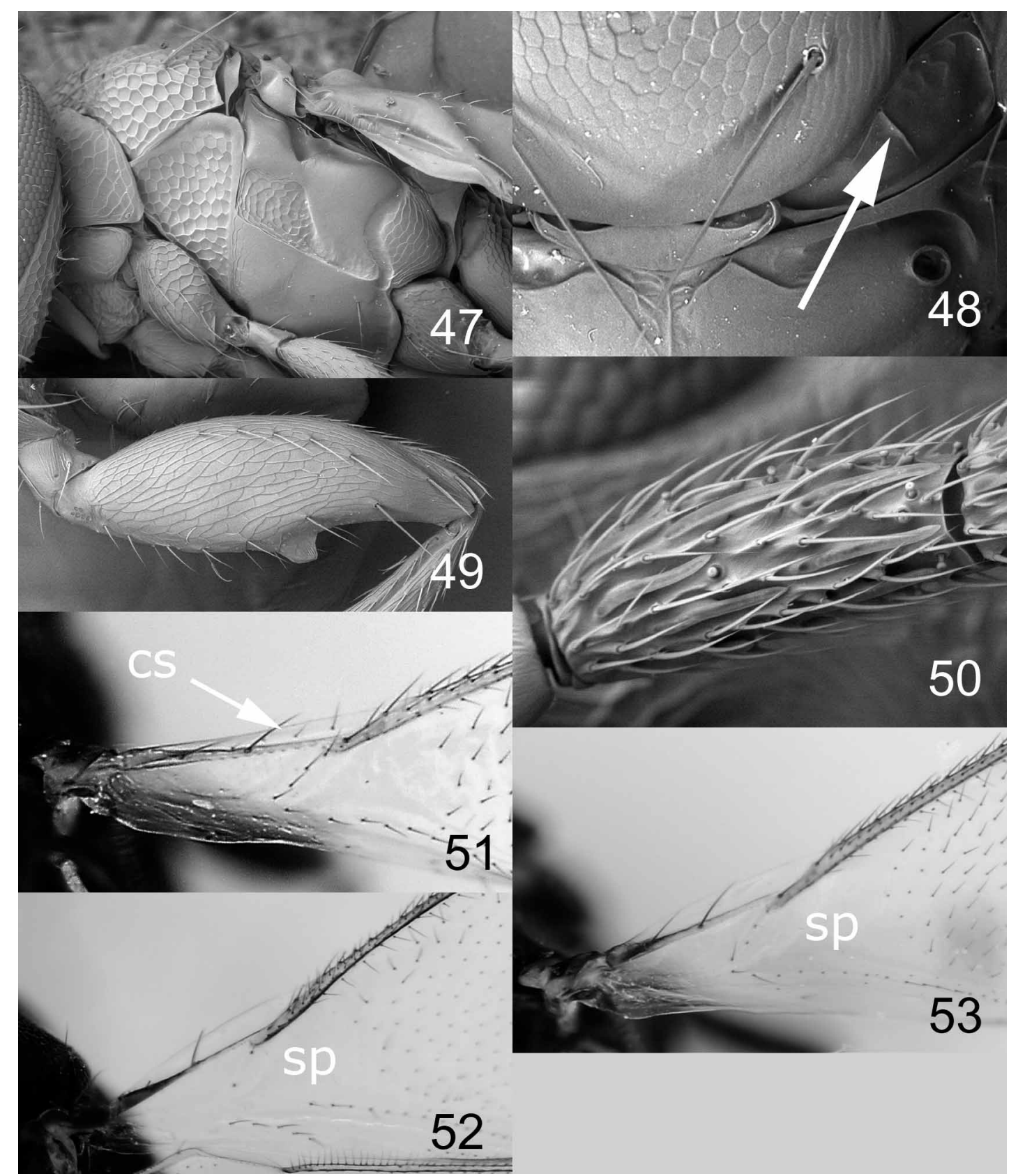

FIGURES 47-53. Dentalion spp., females. 47. D. pinguicornis sp. nov., mesosoma lateral. 48. D. pinguicornis, right-hand lateral panel of metanotum, arrow points to longitudinal carina that divides panel into two about equal-sized parts. 49. D. noyesi sp. nov., hind femur lateral. 50. D. apertum sp. nov., first funicular segment. 51. D. apon sp. nov., base of forewing. 52 . $D$. apertum, base of forewing. 53. D. noyesi, base of forewing. Abbreviations: cs = costal cell with row of setae; sp = speculum. 


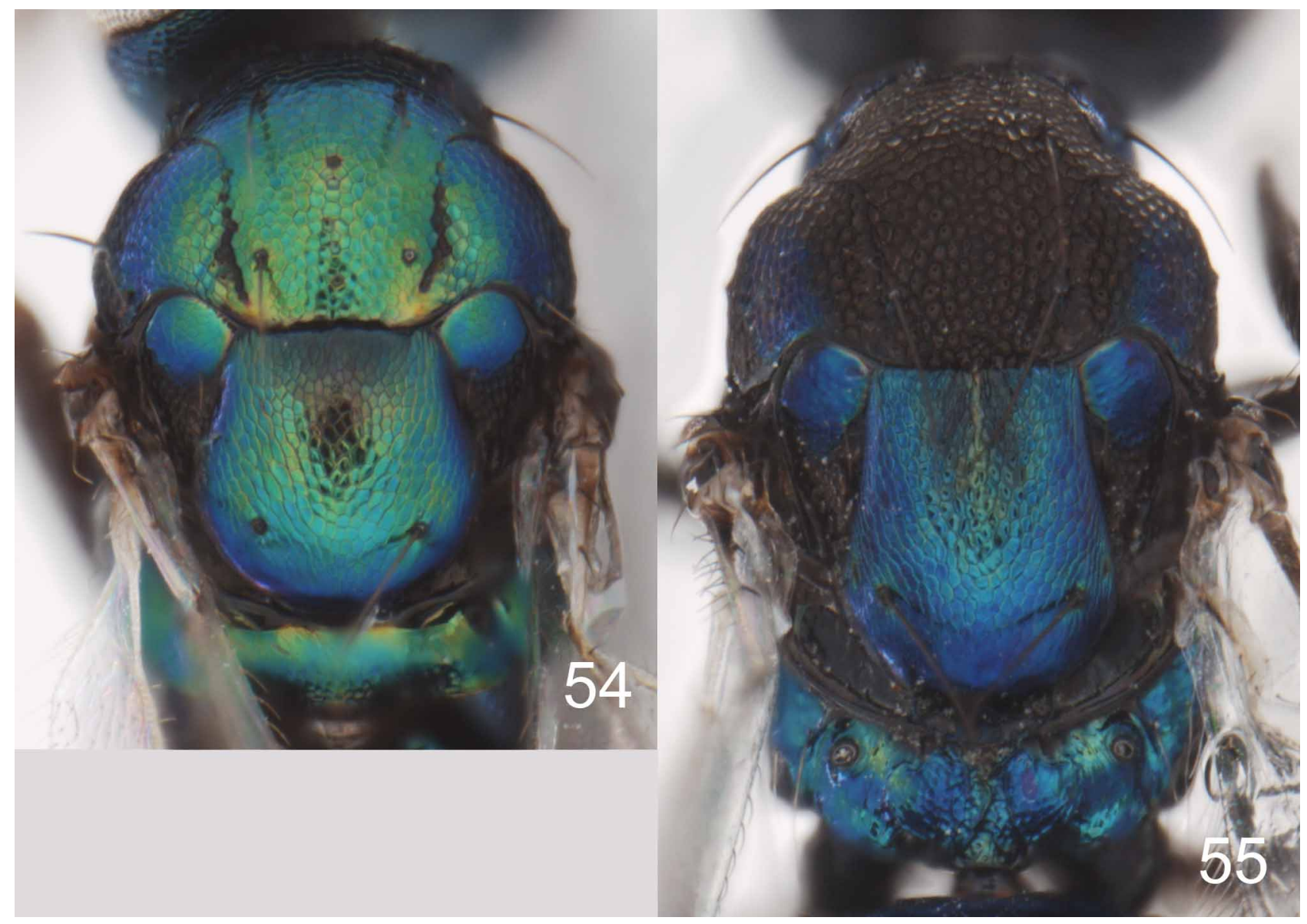

FIGURES 54, 55. Dentalion spp., females, mesosoma dorsal. 54. D. crassicornis $\mathbf{s p . ~ n o v . . ~ 5 4 . ~ D . ~ p i n g u i c o r n i s ~} \mathbf{s p . ~ n o v . ~}$

\section{Dentalion quadrifer sp. nov.}

(Figs 1, 43-46, 69)

Diagnosis. Scutellum with 2 pairs of setae, one anterior and one posterior (Fig. 44); frontal suture reaching eyes at a level equal to half distance between posterior margin of anterior ocellus and anterior margin of posterior ocelli (Fig. 46); forewing costal cell ventrally with a sparse row of setae in apical 1/2 (as in Fig. 51).

Similar to D. apon but frons and vertex with much stronger reticulation (Figs 43,46 ), and mesoscutum and scutellum with distinctly smaller meshes (Fig. 44).

Description. FEMALE. Length $2.0 \mathrm{~mm}$. Scape yellowish-brown with dorsal edge dark brown, pedicel and flagellum dark brown. Frons metallic bluish-green. Vertex golden-green. Mesoscutum, scutellum and propodeum metallic bluish-green. Coxae dark and metallic; femora and tibiae dark brown; tarsi with tarsomeres 1-3 white, 4 dark brown. Forewing hyaline. Gaster with tergite 1 metallic bluish-green, remaining tergites dark brown with metallic tinges.

Antenna as in Fig. 69. Frons with raised, strong reticulation (Fig. 43); frontal suture reaching eyes at a level equal to half distance between posterior margin of anterior ocellus and anterior margin of posterior ocelli. Vertex with raised, strong reticulation (Fig. 46). Occipital margin rounded. Eyes with sparse, scattered hairs (Figs 43, 46).

Pronotum without transverse carina close to posterior margin (Fig. 44). Mesoscutum with raised, strong reticulation (Fig. 44); notauli as narrow distinct grooves in anterior $1 / 3$, not visible in posterior $2 / 3$. Scutellum with raised, strong reticulation (Fig. 44); with 2 pairs of setae. Propodeum with very weak reticulation and with irregular longitudinal carinae medially (Fig. 45); callus with 2 setae. Forewing speculum closed below; costal cell ventrally with a sparse row of setae in apical $1 / 2$.

Petiole 0.4X as long as wide, smooth. Gaster elongate with apex acuminate; tergites smooth.

MALE. Unknown. 


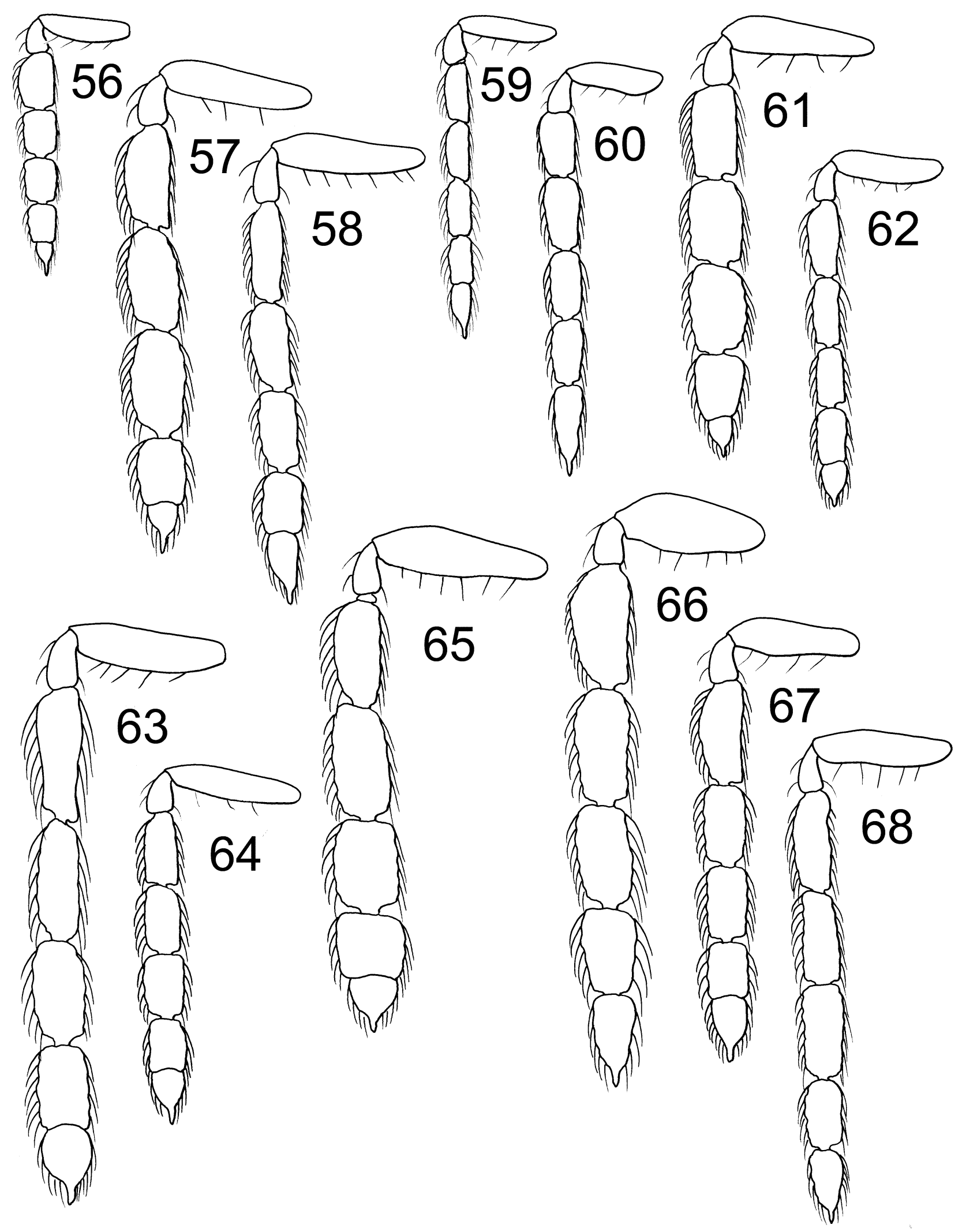

FIGURES 56-68. Dentalion spp., antenna lateral. 56. D. alveum, female. 57. D. ambonatum, female. 58. D. apertum, female. 59. D. apon, female. 60. D. apon, male. 61. D. crassicornis, female. 62. D. jimenezi, female. 63. D. mischum, female. 64. D. jimenezi, male. 65. D. pinguicornis, female. 66. D. noyesi, female. 67. D. pinguicornis, male. 68. D. pnigaliae, female. 
Material examined. Holotype female (BMNH) labelled "COSTA RICA, Limón, $0.5 \mathrm{~km}$ E Braulio Carrillo National Park, San José-Limón road, 400 m, 9.ii.1991, J.S. Noyes".

Etymology. Named for the four setae on scutellum, from the Latin quadrus $=$ four, and the suffix $-f e r=$ carry.

Distribution. Costa Rica.

Remarks. The antennae are broken on the single available specimen. The left pedicel and flagellum on the left antenna, and the apical two flagellomeres are detached and glued separately on the card.

\section{Acknowledgements}

For loan of material I am indebted to Roy Danielsson (LUZM), John Noyes (BMNH), and the staff at INBio especially Iván Jiménez, formerly parataxonomist at INBio, who collected a substantial amount of the material of Dentalion. I also acknowledge the Department of Biology, Lund University for the use of their SEM facility.

\section{References}

Hansson, C. (1990) A taxonomic study on the Palearctic species of Chrysonotomyia Ashmead and Neochrysocharis Kurdjumov (Hymenoptera, Eulophidae). Entomologica Scandinavica, 20, 29-52.

Hansson, C. (1996) A new genus of Eulophidae (Hymenoptera: Chalcidoidea) with remarkable male genitalia. Systematic Entomology, 21, 39-62.

Hansson, C. (2002) Eulophidae of Costa Rica, 1. Memoirs of the American Entomological Institute, 67, 1-290.

Hansson, C. (2004) Eulophidae of Costa Rica, 2. Memoirs of the American Entomological Institute, 75, 1-536.

Hansson, C. (2009a) Eulophidae of Costa Rica, 3. Memoirs of the American Entomological Institute, 82, 1-916.

Hansson, C. (2009b) The genus Microdonophagus Schauff (Hymenoptera: Eulophidae), with description of a new species. Zootaxa, 2200, 54-60.

Hansson, C. (2010) Inti (Hymenoptera: Eulophidae) a peculiar new genus from tropical America. Zootaxa, $2729,58-64$.

Schauff, M.E. \& Janzen, D.H. (2001) Taxonomy and ecology of Costa Rican Euplectrus (Hymenoptera: Eulophidae), parasitoids of caterpillars (Lepidoptera). Journal of Hymenoptera Research, 10, 181-230.

Schauff, M.E., La Salle, J. \& Coote, L.D. (1997) Eulophidae. Pp 327-429, in Gibson, G.A.P., Huber, J.T. \& Woolley, J.B. (eds.), Annotated Keys to the Genera of Nearctic Chalcidoidea (Hymenoptera). National Research Council Research Press. Ottawa, Ontario, Canada. 794 pp. 